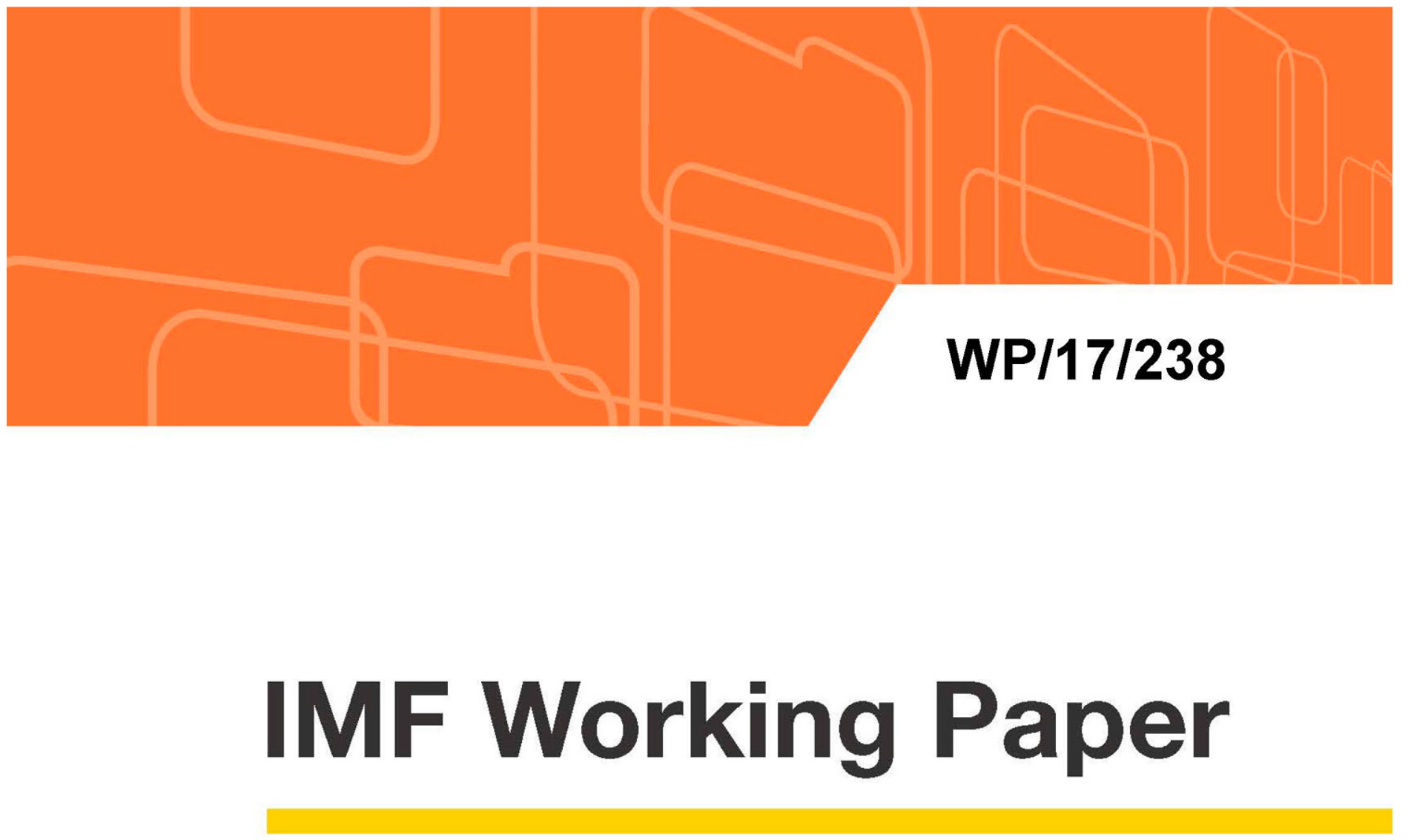

\title{
Potential Growth in Colombia
}

by Sergi Lanau, José Daniel Rodríguez-Delgado, and Jorge Roldós

IMF Working Papers describe research in progress by the author(s) and are published to elicit comments and to encourage debate. The views expressed in IMF Working Papers are those of the author(s) and do not necessarily represent the views of the IMF, its Executive Board, or IMF management. 


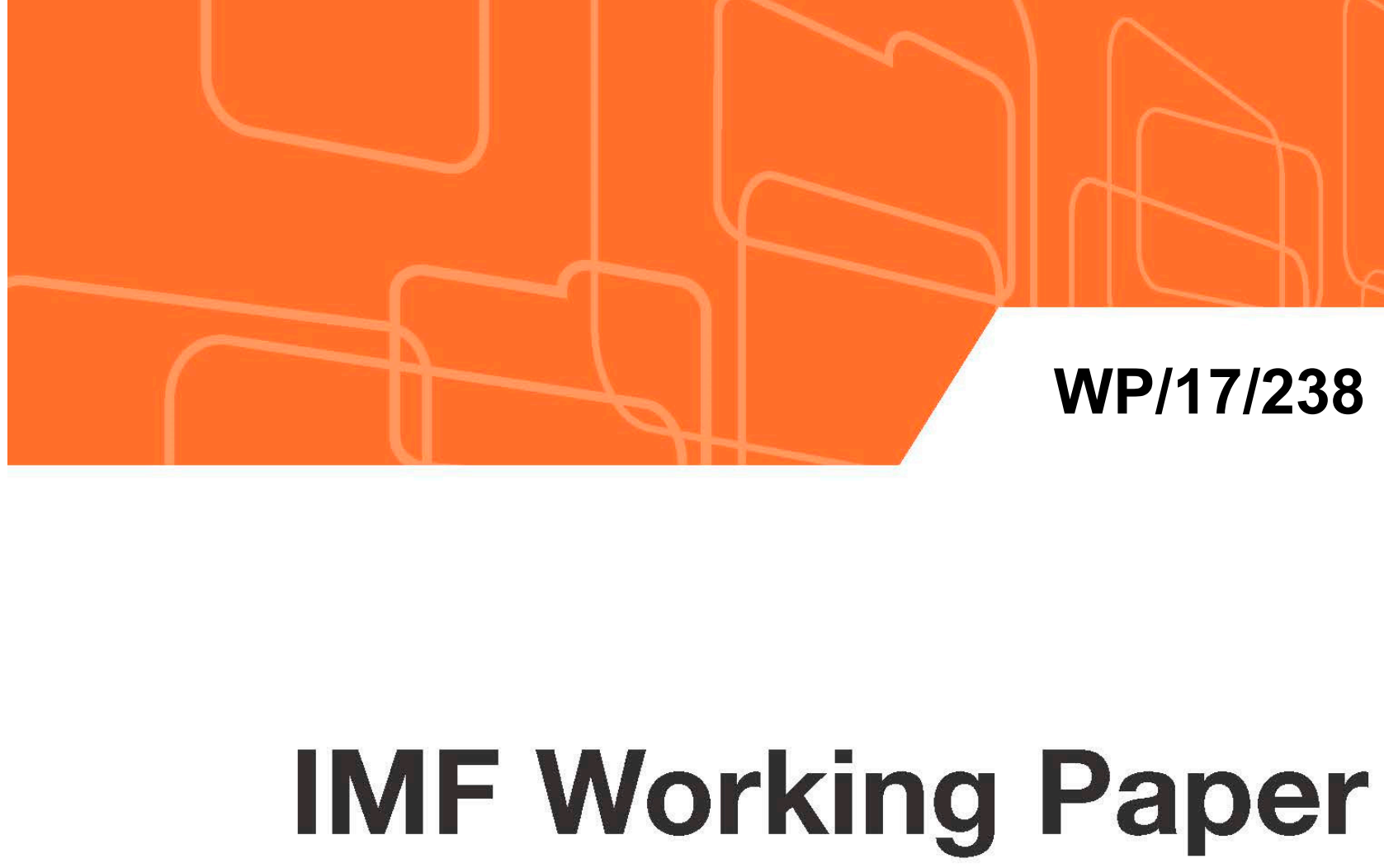

\section{Potential Growth in Colombia}

by Sergi Lanau, José Daniel Rodríguez-Delgado, and Jorge Roldós

IMF Working Papers describe research in progress by the author(s) and are published to elicit comments and to encourage debate. The views expressed in IMF Working Papers are those of the author(s) and do not necessarily represent the views of the IMF, its Executive Board, or IMF management. 


\title{
IMF Working Paper
}

Western Hemisphere Department

\section{Potential Growth in Colombia}

\section{Prepared by Sergi Lanau, José Daniel Rodríguez-Delgado, and Jorge Roldós}

\author{
Authorized for distribution by Jorge Roldós
}

November 2017

\section{IMF Working Papers describe research in progress by the author(s) and are published to elicit comments and to encourage debate. The views expressed in IMF Working Papers are those of the author(s) and do not necessarily represent the views of the IMF, its Executive Board, or IMF management.}

\begin{abstract}
This paper uses a multivariate filter and a production function to project potential growth in Colombia, modeling in detail the impact of low oil prices on investment. The framework also captures the impact of current and planned policies on potential growth, including the peace agreement with the FARC, the tax reform, and $4 \mathrm{G}$ infrastructure projects. The analysis suggests the growth acceleration of the 2000s is unlikely to repeat itself in a world of lower oil prices. Potential growth is likely to moderate to a range of 2.8 to 4.1 percent. The $4 \mathrm{G}$ infrastructure projects and the tax reform will increase investment, partly offsetting the sharp decline in oil investment. Improvements in productivity are essential to lift potential growth, as the large increases in the labor force observed in the last 15 years are unlikely to continue.
\end{abstract}

JEL Classification Numbers: E10, E20, E32, E44

Keywords: Potential output; Colombia; Investment.

Author’s E-Mail Address: slanau@imf.org,jrodriguezdelgado@imf.org,jroldos@imf.org 


\section{Table of Contents}

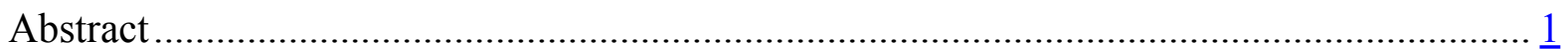

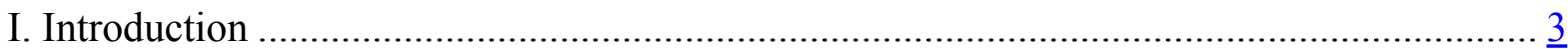

II. A statistical app roach to potential growth........................................................... $\underline{3}$

III. Production Function Approach ............................................................................. $\underline{5}$

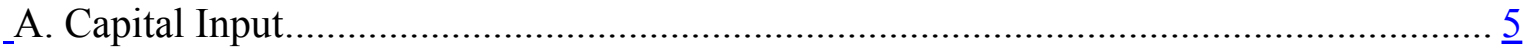

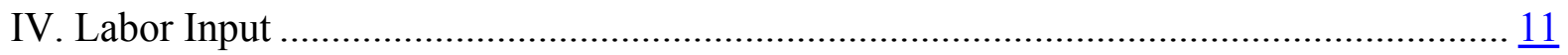

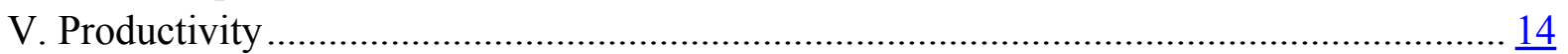

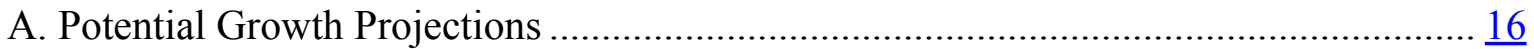

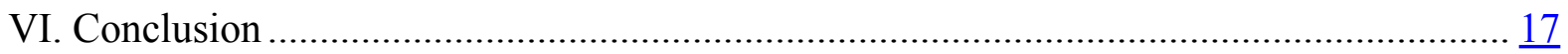

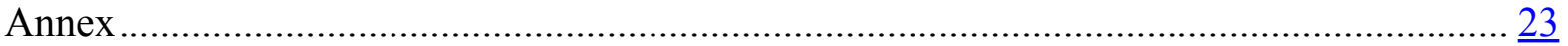

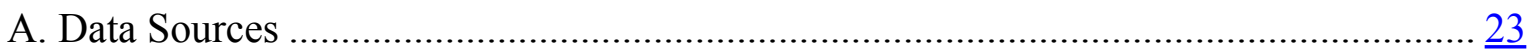

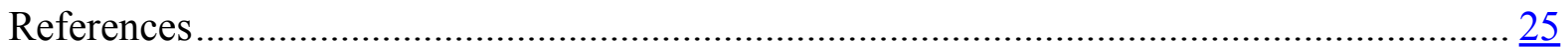




\section{INTRODUCTION}

Colombia experienced an extended period of high growth up until 2014, against a background of rising commodity prices. GDP growth averaged 4.3 percent in 2000-14, while oil prices increased 241 percent. A liberalization of the oil sector allowed the country to further take advantage of the oil price boom, by roughly doubling oil production to around a million barrels per day from 2007 to $2014 .{ }^{1}$ A large increase in labor participation and formalization also supported this growth acceleration, as did strong global demand conditions (Colombia's trading partners grew at an average of 3.6 percent in 2000-14).

In contrast, the sharp and largely permanent decline in oil and other commodity prices since 2014 have taken a toll on growth. GDP grew 3.1 and 2.0 percent in 2015 and 2016, respectively, as exports declined and domestic demand started adjusting to a lower level of national income. Investment decelerated markedly and even declined in 2016, as oil prices more than halved and trading partner growth turned negative. As noted in IMF (2015a), oil exporters were expected to grow around 2 percent below trend growth and, more importantly, they would experience lower rates of potential GDP growth going forward.

In this context, this paper addresses the issue of Colombia's growth prospects in a world of lower oil prices. Part of the recent economic slowdown is a temporary phenomenon associated to the transition to weaker terms of trade as Brent oil prices declined from about 102 dollars per barrel in mid-2014 to about 35 dollars in early 2016 and are projected to average about 50 dollars per barrel during the next five years. It is, however, unlikely that Colombia will permanently return to the high growth rates of the early $2000 \mathrm{~s}$. A number of factors suggest that the growth acceleration that started in 2004 (IMF 2017a, Chapter 2) is unlikely to be repeated in the near term. This paper assesses the prospects for medium-term growth in Colombia in a world of lower oil prices building on the insights from a multivariate filter (Section B) and disentangling potential sources of growth using a production function approach (Section $\mathrm{C}$ ).

\section{A STATISTICAL APP ROACH TO POTENTIAL GROWTH}

Multivariate filters (MVFs) are a useful tool to explore the implications for potential GDP growth of the relationship between oil prices and actual GDP. This section discusses the results of an application of the MVF in Blagrave and Santoro (2016) to Colombia. The details of the MVF are discussed in the annex but the intuition behind the methodology is relatively straightforward. Based on the path of actual GDP and oil prices the model:

\footnotetext{
${ }^{1}$ In 2003, Colombia liberalized and restructured the oil sector, modifying the contract and taxation frameworks, as well as moving the regulatory function away from the major state-owned oil company (Ecopetrol) to an independent agency (ANH).
} 
- Decomposes the oil price into a cyclical and structural components. Not surprisingly, the filter assigns a large share of the commodity price boom of the 2000s to the cyclical component of oil.

- Assumes that the structural price of oil, i.e. longlasting changes in prices, positively affects potential output. The filter is silent on the economic forces that link oil price trends and potential output but, as discussed by Aslam and others (2016), there is a rationale for the correlation. Changes in oil prices that are judged

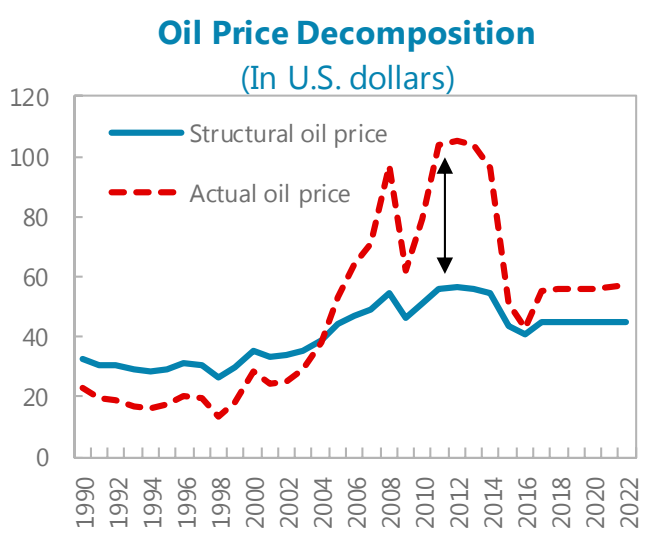

Source: IMF staff calculations. to be permanent will influence hiring and investment decisions in the oil sector and will affect the permanent income fiscal authorities and consumers factor into their choices. Colombia's oil-related investment boom in the second part of the 2000s seems consistent with this intuition as discussed later in this document.

- Assumes that changes in the cyclical component of oil prices affect the output gap but not potential output. In other words, temporary deviations of the oil price from its trend increase GDP temporarily but do not affect the supply side of the economy since shortlived swings in the price of oil do not lead to permanent changes in staffing and investment plans in the oil sector.

The MVF points to weaker potential growth in a world of permanently lower commodity prices (Figure 1). Persistent oil price increases (the MVF structural price increased from about US\$30 a barrel in 1999 to about US\$50 a barrel in 2008) and high actual growth pushed up potential growth estimates in the 2000s. The large drop in oil prices starting in 2014 and the subdued outlook for the oil market change the picture completely though. The MVF estimates potential growth of just 3 percent in 2016 and a gradual recovery to 3.5 percent by 2022 . The results echo Gruss (2014), who finds that growth for the average commodity exporter in Latin America is expected to soften.

\section{Figure 1. Potential Growth from Multivariate Filter} (In percent)

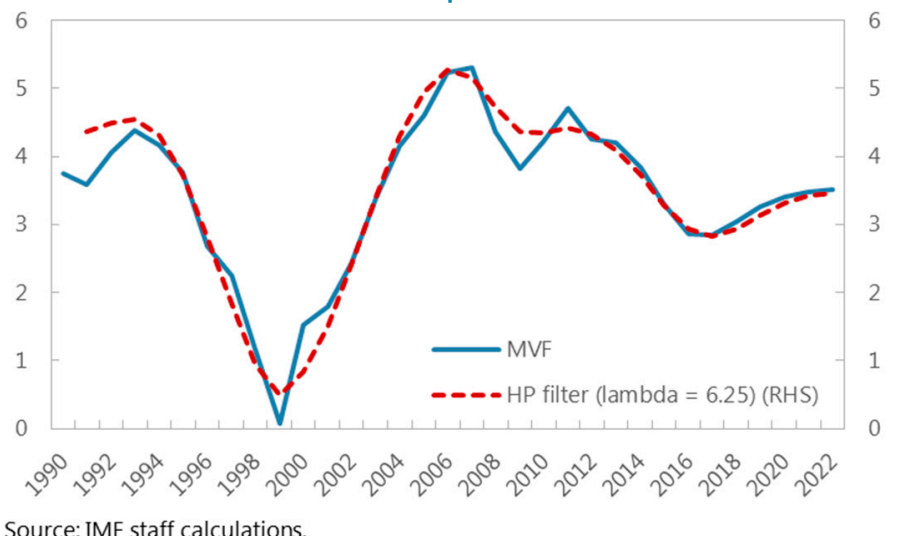


The results of the MVF can be interpreted as an estimation of trend growth informed by oil prices. The MVF follows closely the trend growth estimates from a standard HP filter with $\lambda=6.25$. This is not surprising since both types of filter smooth out economic series to extract trends. While lacking the granularity of a production function, the MVF confirms there is a statistically significant co-movement between growth and oil prices. Given the weak outlook for commodity prices in the near-future, the MVF suggests that a return to the very high GDP growth rates of the mid-2000s and 2010-13 is unlikely. Note that in the projection period the MVF is heavily influenced by the IMF WEO projections for actual GDP growth (the standard end-point problems in HP filters). The next section looks at the evolution of labor, capital, and productivity and their implications for growth in a more structural way.

\section{Production Function Approach}

\section{Production function methods use information on capital and labor inputs, and} productivity to estimate potential growth. This paper applies a methodology similar to Havik and others (2014) to estimate and project potential output in Colombia for the period 1990-2022, taking into account the impact of permanently lower commodity prices and stated government policies on investment, labor markets, and productivity. The production function takes the following form

$$
Y=A K^{\alpha} L^{1-\alpha}
$$

where $Y$ is potential output, $A$ is total factor productivity, $K$ is the capital stock in the economy, $L$ is the potential labor input, and $1-\alpha$ is the labor share in national income. Potential growth is calculated as $\Delta \ln (A)+\alpha \Delta \ln (K)+(1-\alpha) \Delta \ln (L)$. A similar decomposition can be made for actual GDP as shown next.

Growth data since the 1990s show that in recent years, factor accumulation made a larger contribution to growth than productivity. Table 1 shows the historical decomposition of the sources of growth in Colombia. Capital and labor accumulation was generally strong. Except for the 2006-10 period, TFP growth was negative or less than one percent. The following subsections delve into the dynamics of each component of the production function. Data sources are listed in the annex.

\section{A. Capital Input}

\section{A historical decomposition of investment growth demonstrates the importance of} commodity export prices for investment. The methodology in IMF (2015b) allows for a decomposition of investment into the contributions of growth in Colombia, global growth, the VIX, commodity export prices, the domestic lending rate, and the real exchange rate (Figure 2). Investment grew on average by about 13 percent annually in 2003-08 and by about 9 percent during 2010-14, when it was underpinned by commodity export prices. 
Similarly, the large commodity-price decline around the Lehman crisis and to a lesser extent during the taper-tantrum, was behind negative spikes of investment growth. In recent quarters, global growth contributed positively to investment but falling commodity prices more than offset the positive effects of global growth. Moreover, the more persistent fall in commodity export prices since 2014 suggests a deeper and more protracted spell of negative investment growth, of a more structural nature. This is likely to be associated with changes in the composition of investment and hints at the importance of looking at the different components of investment and the capital stock. Some estimations along these lines are presented next.

\begin{tabular}{|c|c|c|c|c|c|c|}
\hline \multicolumn{7}{|c|}{ Table 1. Historical Decomposition of Actual GDP Growth } \\
\hline \multicolumn{2}{|c|}{ GDP growth } & \multirow{2}{*}{$\begin{array}{r}\text { Capital } \\
-0.5\end{array}$} & \multirow{2}{*}{$\begin{array}{r}\text { Labor } \\
4.1\end{array}$} & \multirow{2}{*}{$\begin{array}{l}\text { TFP } \\
-1.3\end{array}$} & \multirow{2}{*}{$\frac{\mathrm{K} / \mathrm{Y}}{1.8}$} & \multirow[t]{2}{*}{$1 / Y$} \\
\hline 1991 & 2.3 & & & & & \\
\hline 1992 & 4.3 & 2.3 & 4.1 & -2.2 & 1.8 & \\
\hline 1993 & 5.6 & 1.7 & 2.9 & 0.9 & 1.8 & \\
\hline 1994 & 5.0 & 3.1 & 2.3 & -0.4 & 1.9 & \\
\hline 1995 & 5.1 & 2.2 & 2.6 & 0.2 & 1.9 & \\
\hline 1991-95 & 4.4 & 1.8 & 3.2 & -0.5 & 1.8 & \\
\hline 1996 & 2.0 & 1.2 & 0.4 & 0.4 & $\overline{2.0}$ & \\
\hline 1997 & 3.4 & 1.9 & 1.8 & -0.3 & 2.0 & \\
\hline 1998 & 0.6 & 0.2 & 2.8 & -2.4 & 2.1 & \\
\hline 1999 & -4.3 & -2.9 & 0.3 & -1.6 & 2.2 & \\
\hline 2000 & 2.9 & 2.7 & 3.2 & -3.1 & 2.1 & 0.137 \\
\hline $1996-2000$ & 0.9 & 0.6 & 1.7 & -1.4 & 2.1 & \\
\hline 2001 & 1.7 & -0.4 & 5.2 & -3.2 & 2.1 & 0.148 \\
\hline 2002 & 2.5 & 1.3 & 1.2 & 0.0 & 2.1 & 0.161 \\
\hline 2003 & 3.8 & 1.7 & 3.6 & -1.4 & 2.1 & 0.172 \\
\hline 2004 & 5.2 & 1.7 & 0.7 & 2.8 & 2.0 & 0.182 \\
\hline 2005 & 4.6 & 2.9 & 2.2 & -0.5 & 2.0 & 0.197 \\
\hline $2001-05$ & 3.6 & 1.4 & 2.6 & -0.5 & 2.1 & 0.172 \\
\hline 2006 & 6.5 & 2.8 & 0.0 & 3.6 & 2.0 & 0.218 \\
\hline 2007 & 6.7 & 2.0 & 1.5 & 3.2 & 2.0 & 0.233 \\
\hline 2008 & 3.5 & 0.3 & 1.9 & 1.2 & 2.0 & 0.247 \\
\hline 2009 & 1.6 & 0.1 & 4.2 & -2.7 & 2.1 & 0.240 \\
\hline 2010 & 3.9 & 2.6 & 3.4 & -2.2 & 2.1 & 0.242 \\
\hline $2006-10$ & 4.4 & 1.6 & 2.2 & 0.6 & 2.0 & 0.236 \\
\hline 2011 & 6.4 & 2.6 & 3.4 & 0.4 & 2.1 & 0.270 \\
\hline 2012 & 4.0 & 2.2 & 2.9 & -1.1 & 2.2 & 0.272 \\
\hline 2013 & 4.8 & 1.7 & 1.8 & 1.2 & 2.2 & 0.277 \\
\hline 2014 & 4.3 & 2.6 & 2.1 & -0.4 & 2.3 & 0.291 \\
\hline 2015 & 3.0 & 0.1 & 2.2 & 0.7 & 2.3 & 0.288 \\
\hline 2016 & 1.9 & 3.7 & 1.1 & -2.8 & 2.4 & 0.272 \\
\hline 2011-16 & 4.1 & 2.2 & 2.2 & -0.3 & 2.3 & 0.278 \\
\hline $\begin{array}{l}\text { Sources: DANE. } \\
\text { Note: growth ra } \\
\text { adjusted by hur } \\
0.66 \text {. }\end{array}$ & $\begin{array}{l}\text { ated } \mathrm{i} \\
\text { I usi }\end{array}$ & $\begin{array}{l}\text { difference } \\
\text { index in }\end{array}$ & $\begin{array}{l}\text { al is util } \\
\text { World }\end{array}$ & $\begin{array}{l}\text { djuste } \\
\text { he lab }\end{array}$ & & \\
\hline
\end{tabular}




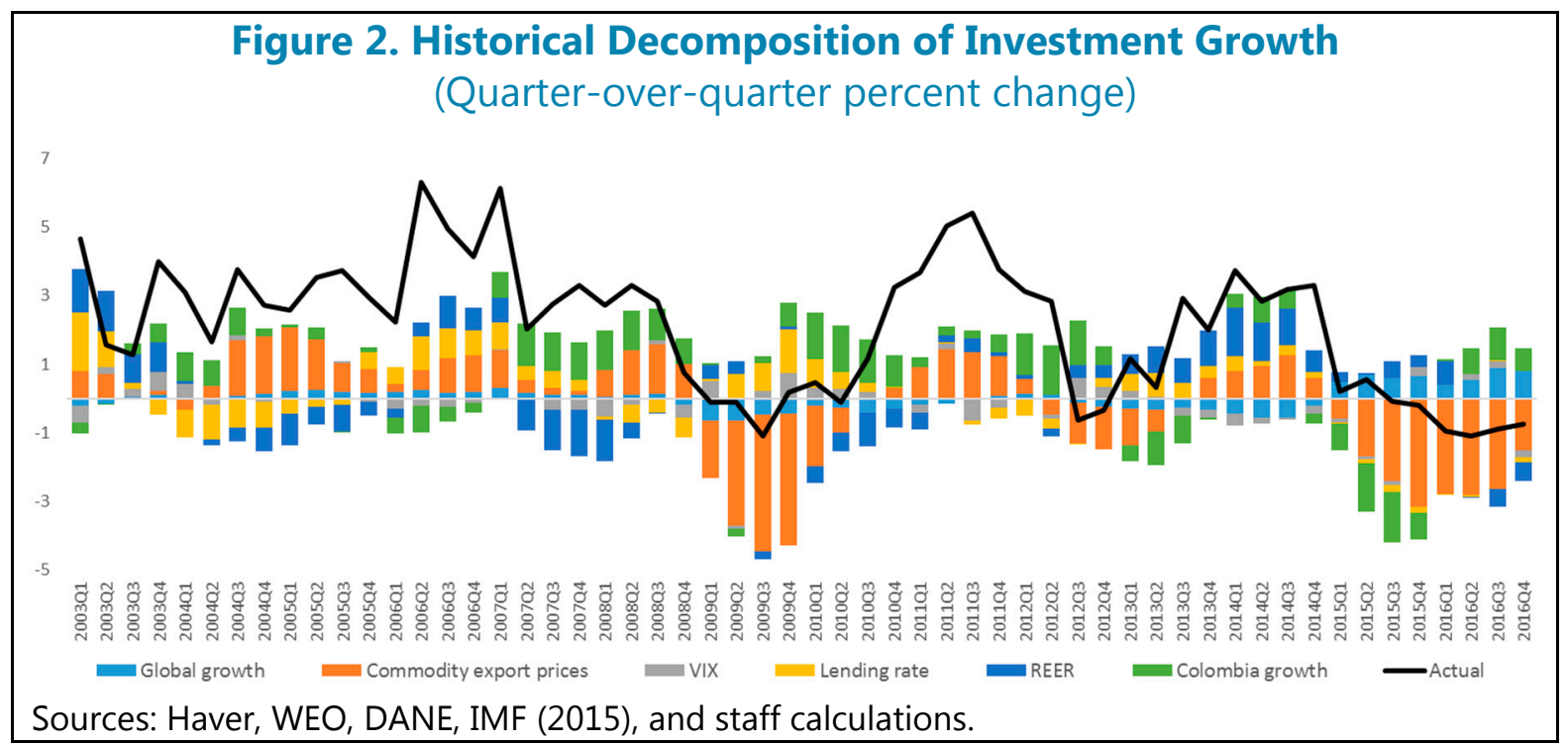

The composition of the capital stock in Colombia changed remarkably in the last three decades as a result of high commodity prices. Structures fell from 95 percent of the total capital stock in the early 1990s to just 85 percent in 2015, whereas machinery and equipment grew from 3 percent to 9 percent of the total (Figure 3). The latter is related to the rapid growth in the oil and mining sectors during the last decade or so. Although a breakdown of the components of the capital stock at the sectoral level is not available, the capital expenditures of Ecopetrol - the largest domestic firm in the oil sector - and FDI to the sector provide some evidence of how much mining investment grew. Figure 3 shows that these two components of investment increased from $2 \frac{1}{2}$ percent of GDP in 2005 to around 4 $\frac{1}{2}$ percent of GDP in 2009-13.

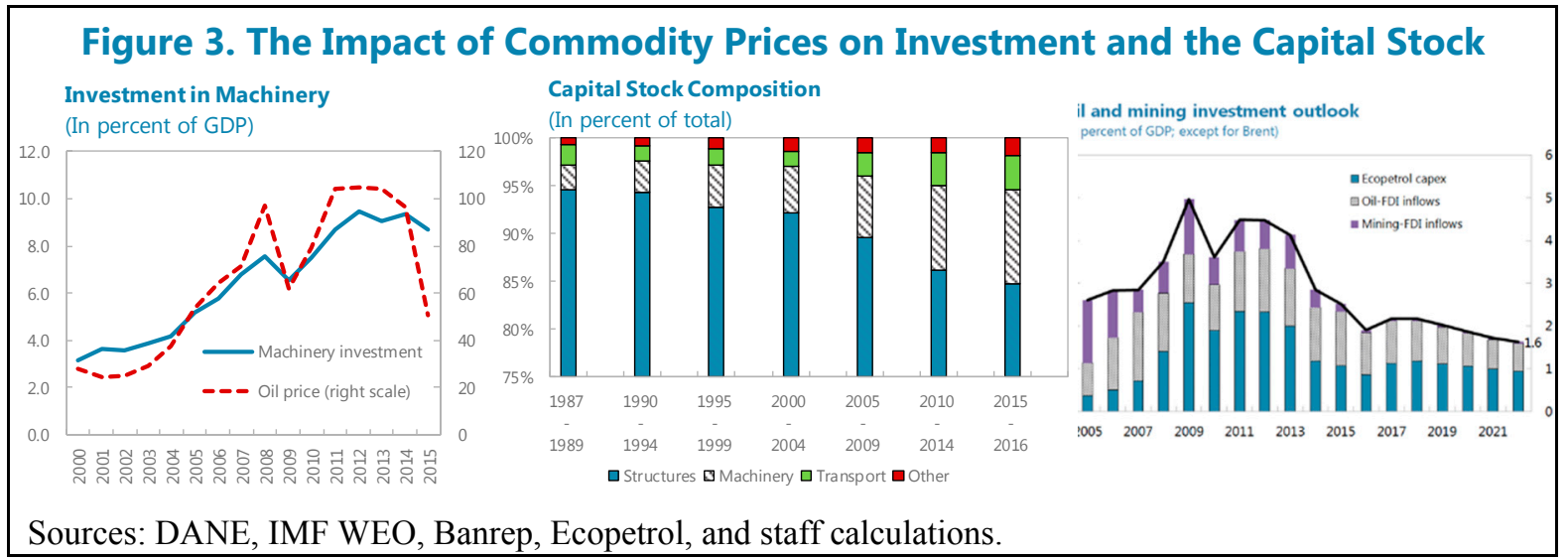

This period of accelerating growth and investment was driven by favorable commodity prices, as well as the timely liberalization of the oil sector by the Colombian authorities. Liberalization allowed domestic and foreign firms to take advantage of the rump up in prices, doubling the production capacity of the sector. IMF (2017a) identifies 2004-13 as a period of growth acceleration in Colombia (see also Hausman and others, 2005), driven to a large 
extent by benign external conditions. Going forward, investment and the growth of the capital stock are likely to slow down and the changes in the composition of the capital stock noted above are likely to be reversed.

In this context, projecting the growth of the capital stock involves a large degree of uncertainty due to the structural changes in the economy as well as the policy responses of the Colombian authorities. On the one hand, lower commodity prices are likely to slow down investment in machinery and equipment. On the other hand, policy responses such as the tax reform (that lowers gradually the effective tax rate on capital), the infrastructure program and the housing subsidies programs, are likely to support investment- - the latter ones mostly on structures.

To control for this high level of uncertainty this paper's projections incorporate a simple regression analysis as well as a number of inputs from previous studies and authorities' projections in their Medium Term Fiscal Framework. We start by regressing the main components of investment on the actual price of oil and an oil-price-gap that uses as long-term or permanent price of oil the one estimated from the MVF of the previous section:

$$
i_{t}^{j}=\alpha+\beta p_{t}^{s}+\delta\left(p_{t}-p_{t}^{S}\right)
$$

where $i_{t}^{j}$ is investment in sector $j$ (machinery and equipment, transport) at time $t$, and $p_{t}, p_{t}^{S}$ are the actual and structural price of oil, respectively. The regressions are estimated for the period 2000-17 using quarterly data, and for projection purposes we use the expected future price of oil as the structural one and set $\delta=0$. To this baseline projection we then add: impact of tax reform (from the aggregate estimates in IMF, 2017c and Box 1), estimates of the capex associated with $4 \mathrm{G}$ infrastructure projects and other public investments, as well as the impact of infrastructure and the peso depreciation on private investment (from Lanau 2017a,b).

Using these inputs, a projection range for the capital stock is calculated from individual forecasts of each component of the capital stock, incorporating the role of oil prices and planned government policies. The lower-bound projection is obtained from a set of regressions by capital type (structures, transportation, machinery and equipment, and other), excluding the impact of planned government policies - the lower bound scenario includes the impact of Colombia Repunta a stimulus package already being implemented in 2017. The upper-bound projection corresponds to a scenario where the potential impact of $4 \mathrm{G}$ infrastructure projects, public investment, the tax reform, and currency depreciation on investment materializes in full. The next few paragraphs delve into the details of the forecast, which are summarized in Table 2. 


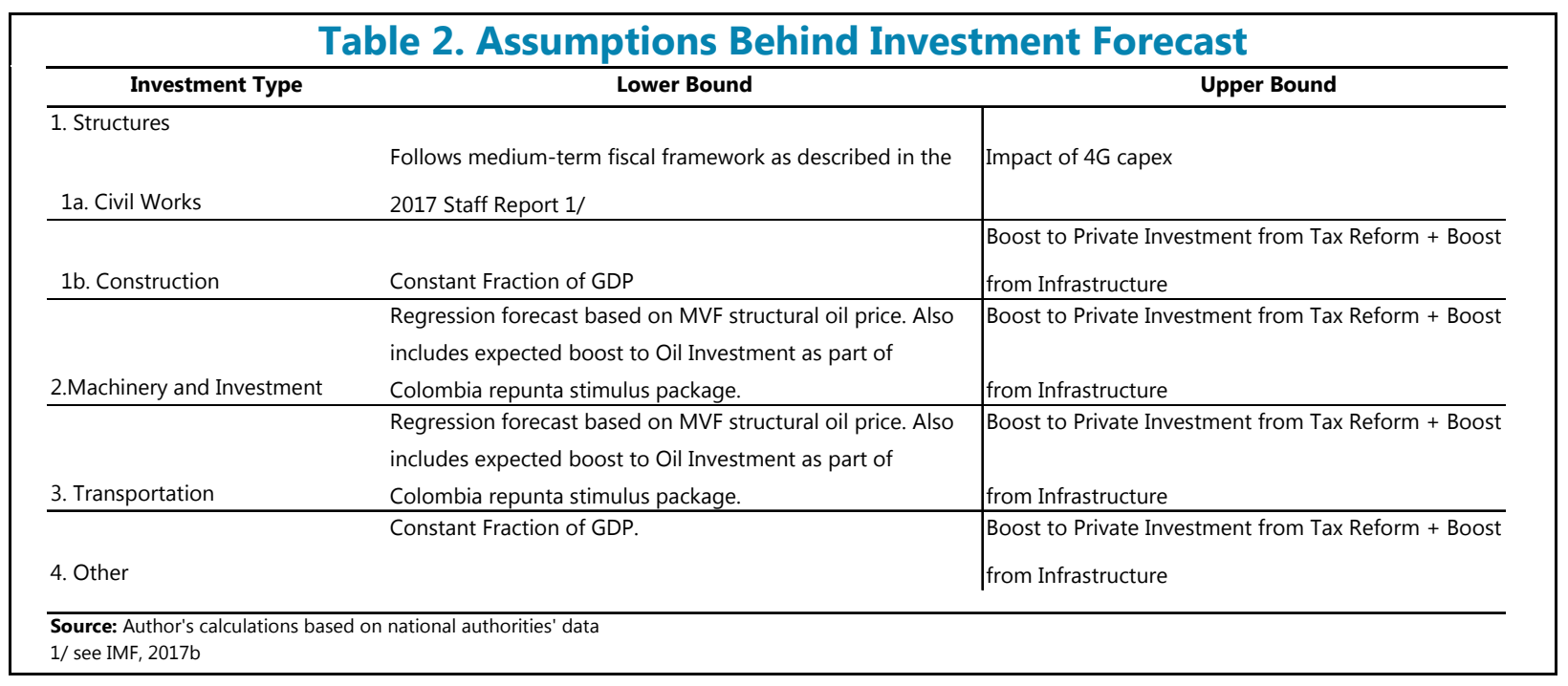

- A regression analysis helps quantify the importance of oil prices in driving investment in transportation and machinery and equipment. The quarterly values of investment in transportation, and machinery and equipment were regressed on their own lagged value as well as structural oil prices and the gap between the actual oil price and the structural price. Structural oil prices are estimated through a MVF as explained in Section A. Table 3 and Figure 4 summarize the regression estimates and forecast. The regression suggests a modest reduction in both machinery and transportation investment as a ratio of GDP.

Table 3. Forecast of Investment in Transportation, and Machinery and Equipment

Regression Results

\begin{tabular}{lrr}
\hline Variable & Coefficient & t-value \\
\hline Sample: Quarterly gross fixed capital formation, 2000Q1-2017Q1 & & \\
Data adjustmnent: 4quarter sum; ratio of GDP & & \\
Type of investment: Machinery and Equipment & 0.90 & 46.82 \\
Lagged investment & 0.00 & 0.01 \\
Structural oil price (US\$ per barrel) & 0.03 & 1.18 \\
Gap between actual and structural oil prices (US\$ per barrel) & 0.01 & 0.16 \\
Lagged Structural oil price (US\$ per barrel) & -0.02 & -0.97 \\
Lagged Gap between actual and structural oil prices (US\$ per barrel) & & \\
& & \\
Type of investment: Transportation & 0.90 & 24.01 \\
Lagged investment & -0.11 & 0.15 \\
Structural oil price (US\$ per barrel) & 0.04 & 1.89 \\
Gap between actual and structural oil prices (US\$ per barrel) & 0.11 & 1.51 \\
Lagged Structural oil price (US\$ per barrel) & -0.04 & -1.83 \\
Lagged Gap between actual and structural oil prices (US\$ per barrel) & & \\
\hline Source: Author's calculations. See text for definition of structural prices & &
\end{tabular}


Figure 4. Machinery and Transportation Investment-Forecast

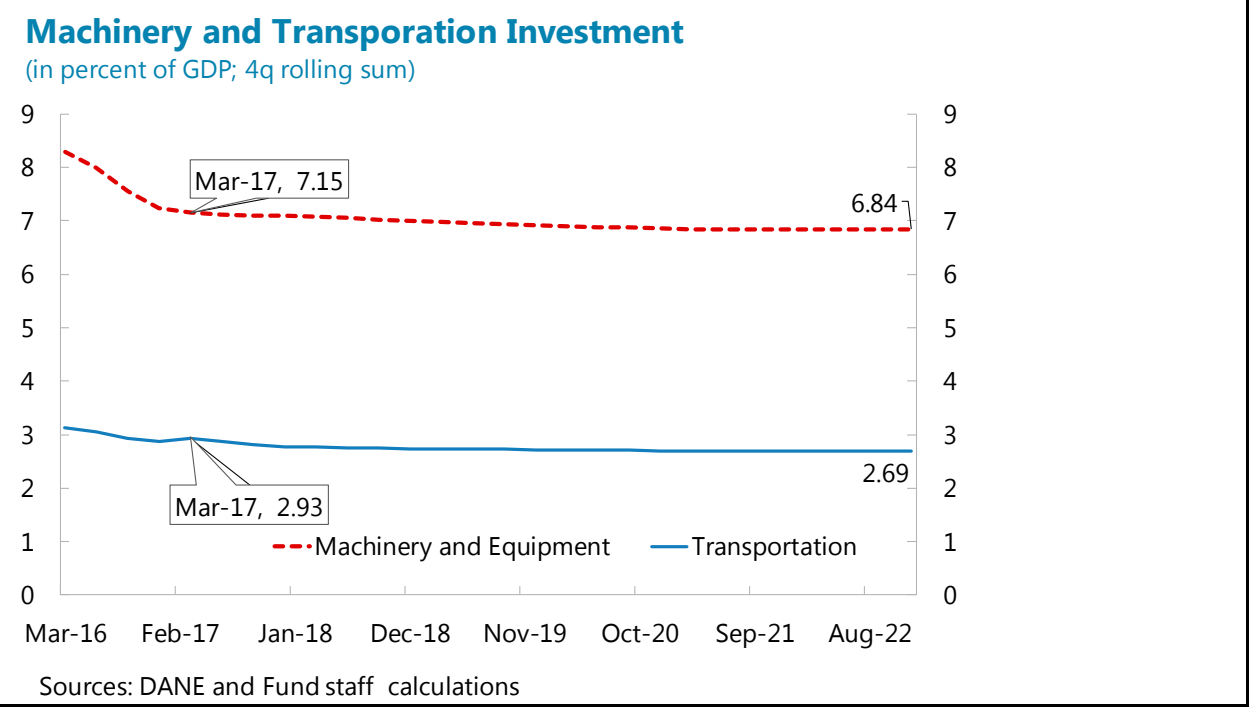

- $\quad$ Government announced public investment plans are used to forecast investment in structures. Structure capital/investment is subdivided into construction and civil works. For simplicity, only civil works are assumed to be affected directly by government investment plans. As a fraction of GDP, investment in civil works is assumed to increase proportionally to the change in the (consolidated public sector, CPS) public investment to GDP ratio as described in IMF (2017b). The simulation also includes a boost to machinery and equipment and transportation investment in 2017 (of about 0.8 percent of GDP combined) which the government expects from the 2017 Colombia Repunta program that inter-alia allows oil companies to offset tax liabilities with additional investment.

- The impact of the $4 \mathrm{G}$ agenda on investment is incorporated into the civil works component of capital. It increases as a percent of GDP in line with the expected 4G capital expenditure (Table 3). The construction phase of 4G infrastructure projects has started and will stretch out to 2023 . It is projected to add up to 0.1 percentage points to the average growth rate of the capital stock in the next 5 years.

\begin{tabular}{|ccccccr|}
\hline \multicolumn{7}{|c|}{ Table 4. 4G Infrastructure Projects: 4G-Related Capex } \\
(In percent of GDP) \\
\hline 2016 & 2017 & 2018 & 2019 & 2020 & 2021 & 2022 \\
\hline 0.23 & 0.94 & 1.17 & 1.05 & 0.81 & 0.37 & 0.08 \\
\hline Source: National Authorities and Fund staff calculations. \\
\hline
\end{tabular}

- The investment forecasts also include the impact of the structural tax reform approved in December 2016. As described in Box 1, the tax reform will lower the corporate tax burden which would boost private investment by about 3.6 percent. To capture this impact, the projection includes a boost to investment, except civil works, of up to 
3.6 percent which adds up to 0.1 percentage points to the average growth rate of the capital stock in 2017-22.

- Infrastructure and the real exchange rate depreciation will increase corporate investment, adding up to 0.1 percentage points to the average growth rate of the capital stock (Box 2, and Lanau 2017a, 2017b). In addition to the aggregate demand and productivity effects of infrastructure, a further contribution to corporate investment is expected from the large real depreciation that accompanied the drop in oil prices. Staff analysis shows exporters invest more in response to depreciations. For example, a firm in the basic metals sector (which is relatively open to trade), would increase its investment rate by 1.4 percentage points in response to a 10 percent real depreciation - the Colombian peso experienced a cumulative real effective depreciation of about 30 percent during 2014-16.

Taking into account the factors discussed above, in a central scenario the capital stock is projected to increase at an annual average rate of around 4.5 percent in 2017-22 (Figure 5). The investment to GDP ratio would remain around 26-27 percent, while the capital stock would grow around 4.3-4.7 percent. The capital/output ratio would climb up to around 2.6, from 2.4 in 2016. The lower bound corresponds to a trend scenario with no impact from $4 \mathrm{G}$ infrastructure projects or tax reform, while the upper bound incorporates the full impact of these policies on investment.

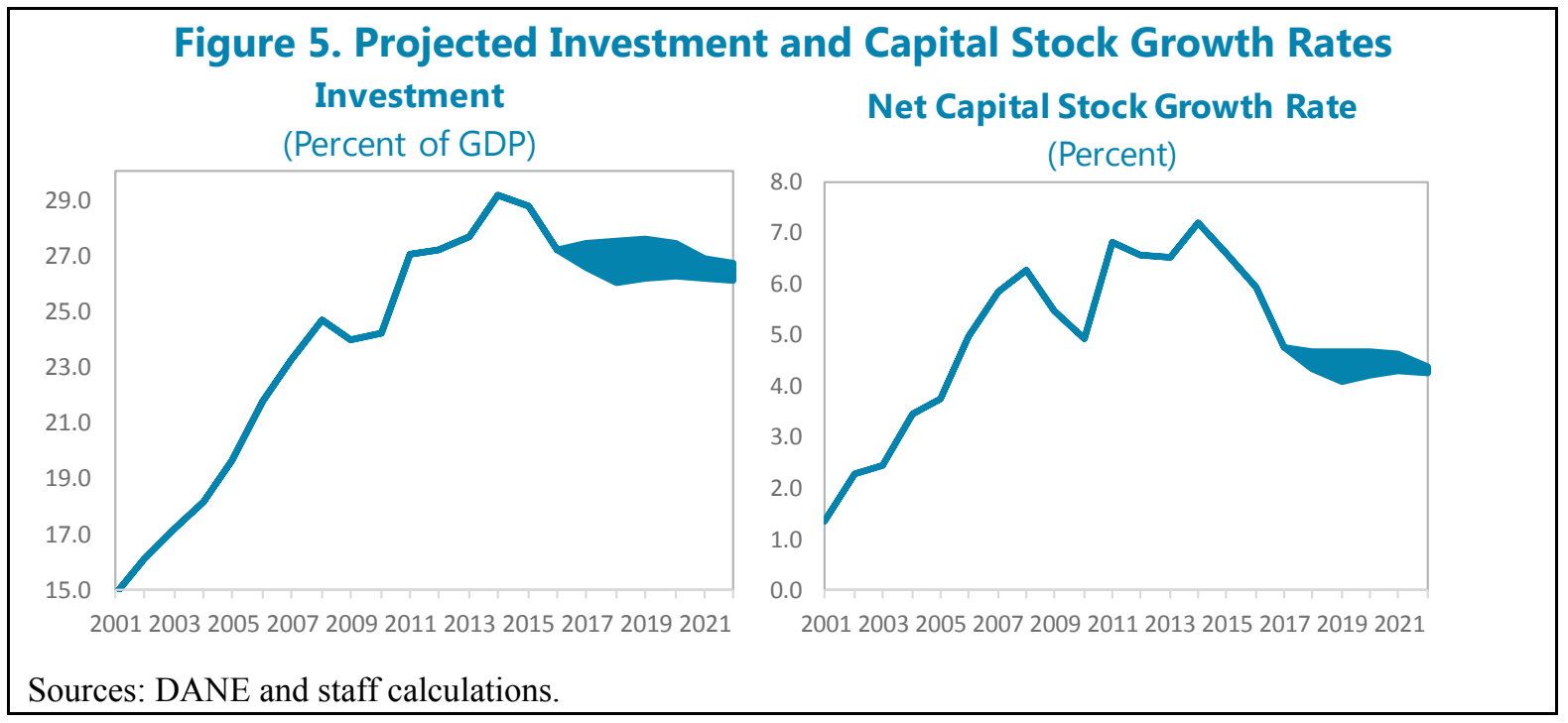

\section{LABOR INPUT}

The labor input to the production function grew strongly since the late 1990s, as a result of both a sharp increase in labor participation and a decline in unemployment. The labor input can be broken down into working age population growth, potential labor force participation rate (LFPR), natural unemployment, and human capital. ${ }^{2}$ As can be seen in

\footnotetext{
${ }^{2}$ Specifically, $L=$ WorkingAgePop $* L F P R *(1-U) *$ HumanK_Index.
} 
Figure 6, the LFPR increased strongly in the 1999 crisis and, after taking a dip in the mid2000s, climbed to an all-time high of 64-65 percent in 2015-16. Similarly, unemployment has been on a declining trend since its peak shortly after the 1999 crisis.

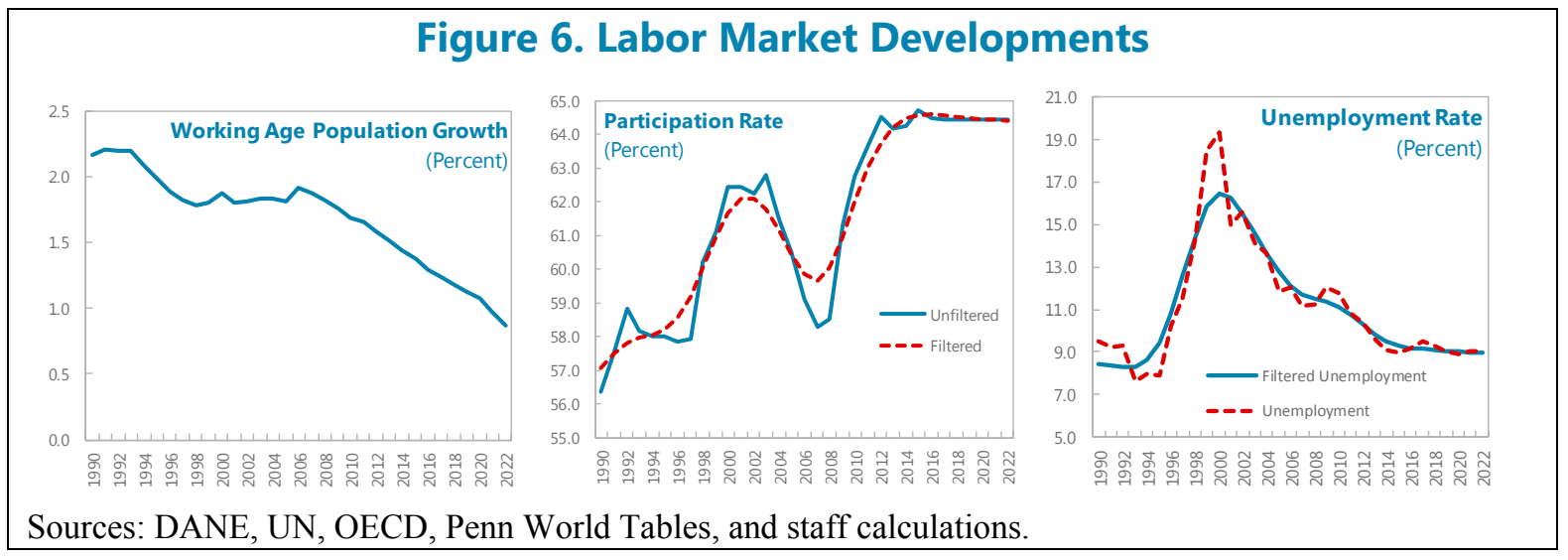

Colombia experienced a steady increase in the human capital stock. The human capital stock constructed from data on average years of schooling (Feenstra and others 2015) increased steadily since 1990 but remains below that of a number of emerging markets.

\section{A trend decline in labor informality likely helped improve the quality of labor inputs. It is well} known that informal labor is less productive than formal one (Perry and others 2007, Dabla-Norris and others 2005). Informality fell 7 percentage points since 2001, indicating that the average quality of the Colombian labor force improved. ${ }^{3}$ The 2012 tax reform, that reduced payroll taxes from 38 percent to about 24.5 percent, accelerated this trend; ${ }^{4}$ and some provisions in the structural tax reform of 2016 might extend it too.

\section{Some of these positive trends may continue over the next decade but their contribution is expected to moderate in the next five years. Potential labor is}

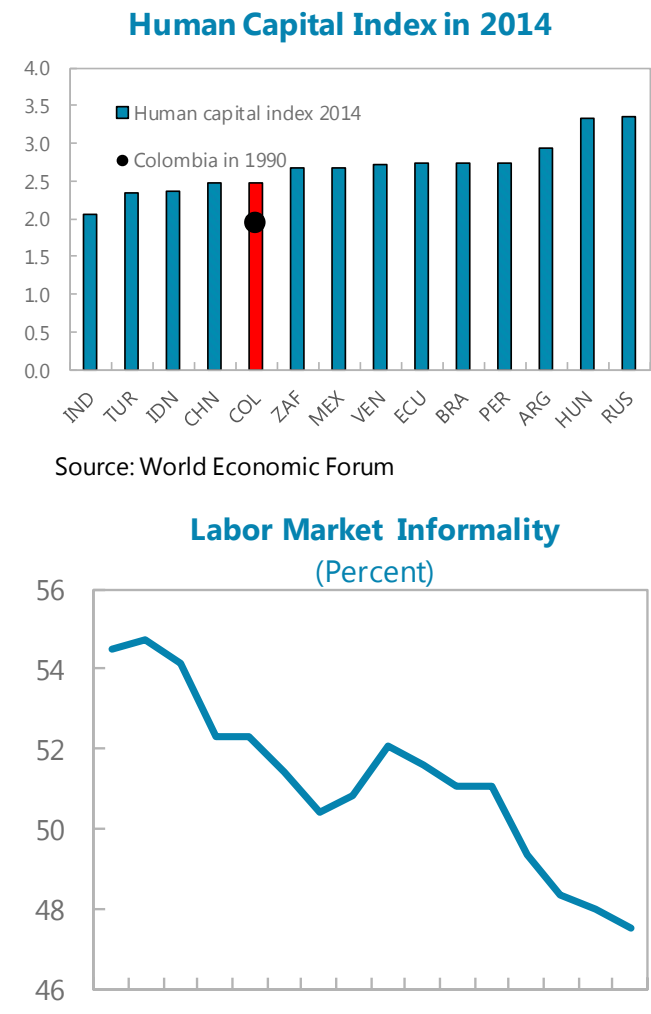

20012003200520072009201120132015

\footnotetext{
${ }^{3}$ Reductions in labor informality show up as improvements in TFP in the accounting framework used in this paper since there is no informality data pre-2001 to adjust labor inputs throughout the sample.

${ }^{4}$ See 2015 Colombia Selected Issues Paper Chapter 2.
} 
projected to grow, slightly above 2 percent per year in 2017-22, sharply down from an average of 3.8 percent in the last five years. Each component is discussed next.

- Decelerating population growth. Similarly to other emerging markets, DANE and UN projections point to slowing demographic trends in Colombia. Working age population is projected to grow at an annual average of 1.1 percent in 2017-22, down from 1.7 percent in $2000-16$.

- Plateauing LFPR. The contribution of the LFPR contribution to the high growth rate of labor inputs was substantial in recent years. The LFPR is projected to remain at around current levels for the projection period since it is already high by international standards. The actual LFPR is filtered to remove its cyclical component and obtain potential participation.

- Falling natural unemployment rate. A modest cyclical uptick is expected in 2017 but as growth picks up, unemployment is projected to fall back to 9 percent. The natural unemployment rate is obtained by filtering actual unemployment.

- Steadily increasing human capital stock. In our projections, it is assumed that the human capital stock continues to increase at an unchanged rate in the next five years (around one percent). In the long-term, the human capital stock may increase faster since the end of the conflict with the FARC will help raise school enrollment rates in the affected areas (Box 3). Improvements in the quality of education (Colombia's PISA scores were weak in 2015), could also boost human capital accumulation in the long run - with a relatively minor impact in the next five years.

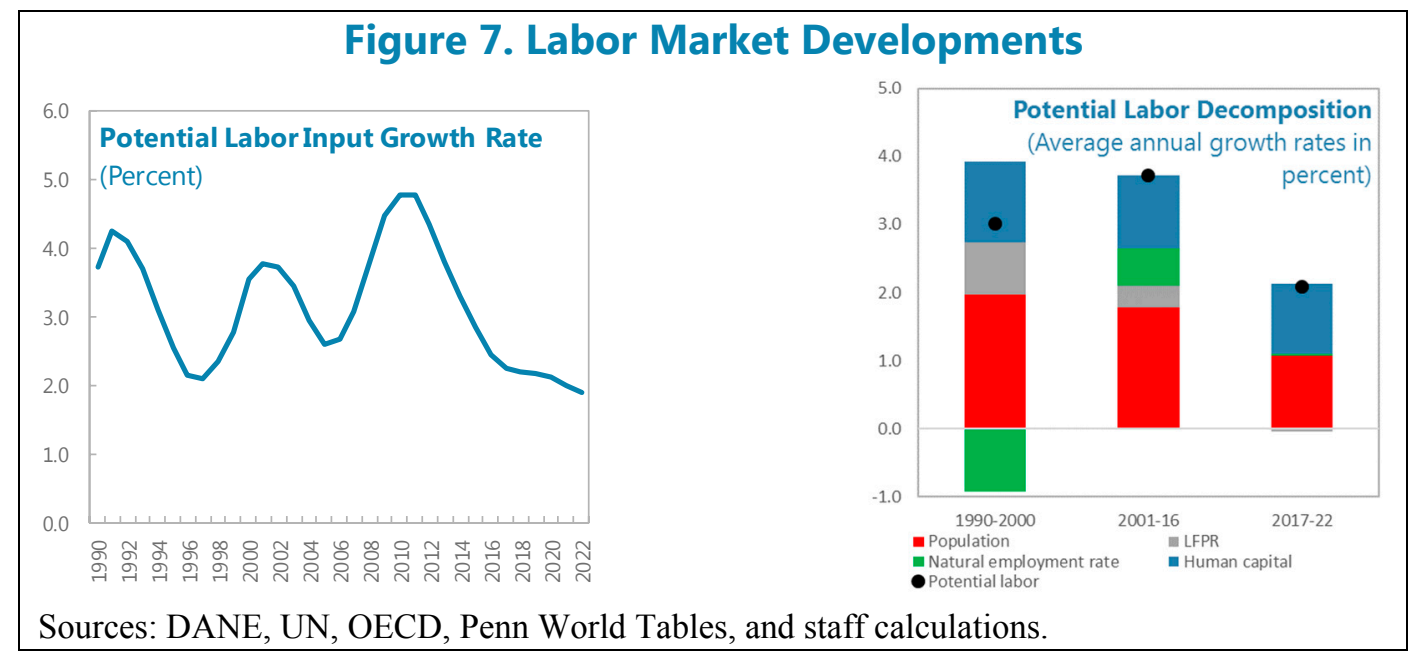




\section{Productivity}

As shown in Table 1, total factor productivity growth has been low except for the period 2004-08 (see also Figure 8). ${ }^{5}$ A number of factors help explain the significant productivity improvements starting at the turn of the century: a sharp reduction in crime, ${ }^{6}$ progress in financial deepening and financial inclusion (Karpowicz 2014), and a better business environment (e.g., cutting almost by half the days it takes to get a construction permit). Favorable terms of trade dynamics may have also been reflected in TFP, as noted in section B. The poor performance in the 1990s is in line with the findings of Sosa and others (2013).

\section{It is important to bear in mind the limitations of TFP as a measure of productivity.}

Since TFP is residual, it can be contaminated by measurement errors in the labor and capital inputs (e.g., changes in the quality of the capital stock or fluctuations in hours worked). Labor productivity in the non-primary sector is an alternative productivity measure often used in the literature. As shown in Figure 8, Colombia's labor productivity grew at a healthy clip in the early 2000s, according to this metric (although part of the improvement is due to capital accumulation, not pure productivity). In international perspective, though, Colombia's productivity is relatively low compared to other EMs.

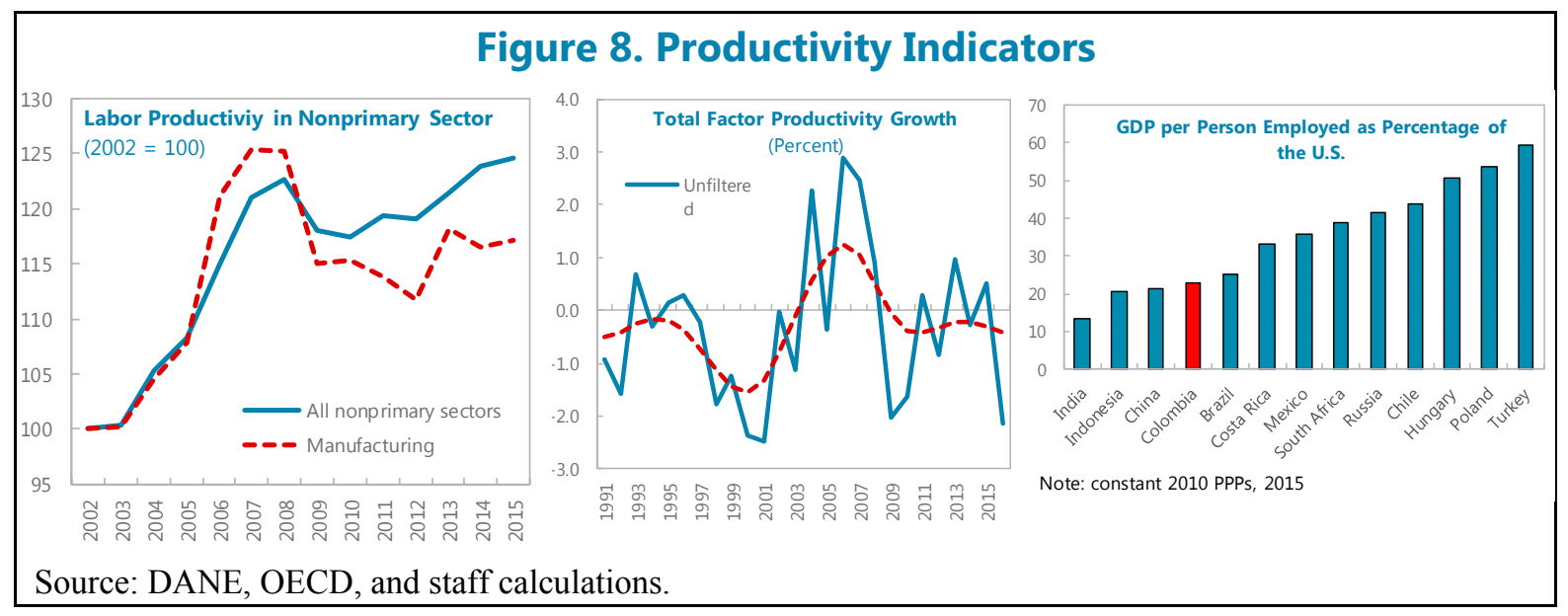

- The recent decline in trend TFP is in line with regional and global trends. It has been influenced by the sharp drop in measured TFP at the time of the financial crisis, which may largely reflect factors such as labor hoarding rather than fundamental productivity changes (Haldane 2017). As Sosa and others (2013) hypothesize, part of the recent decline in TFP could be related to the expansion of mining into areas of lower

\footnotetext{
${ }^{5}$ TFP is obtained as a residual from the log version of equation (1), using actual GDP, the capital stock adjusted by utilization, and actual employment adjusted by human capital. Potential TFP is the result of applying an HP filter $(\lambda=6.25)$ to the TFP residual.

${ }^{6}$ See Cardenas and Rozo (2002) on the link between crime and productivity in Colombia.
} 
marginal productivity where production became profitable due to the commodity price boom.

Aggregate TFP figures mask large productivity differentials across firms and regions (Figure 9). OECD (2017) provides an overview of key indicators for productivity diagnosis with an emphasis on industry and firm level variables. As Brown and others (2013) document, the dispersion in firm productivity is larger in Colombia than in OECD countries. IMF (2017d) finds evidence of resource misallocation in the manufacturing sector in Colombia (Figure 9). The degree of misallocation is moderate in international perspective but correcting it could increase growth by 0.3 percentage points.

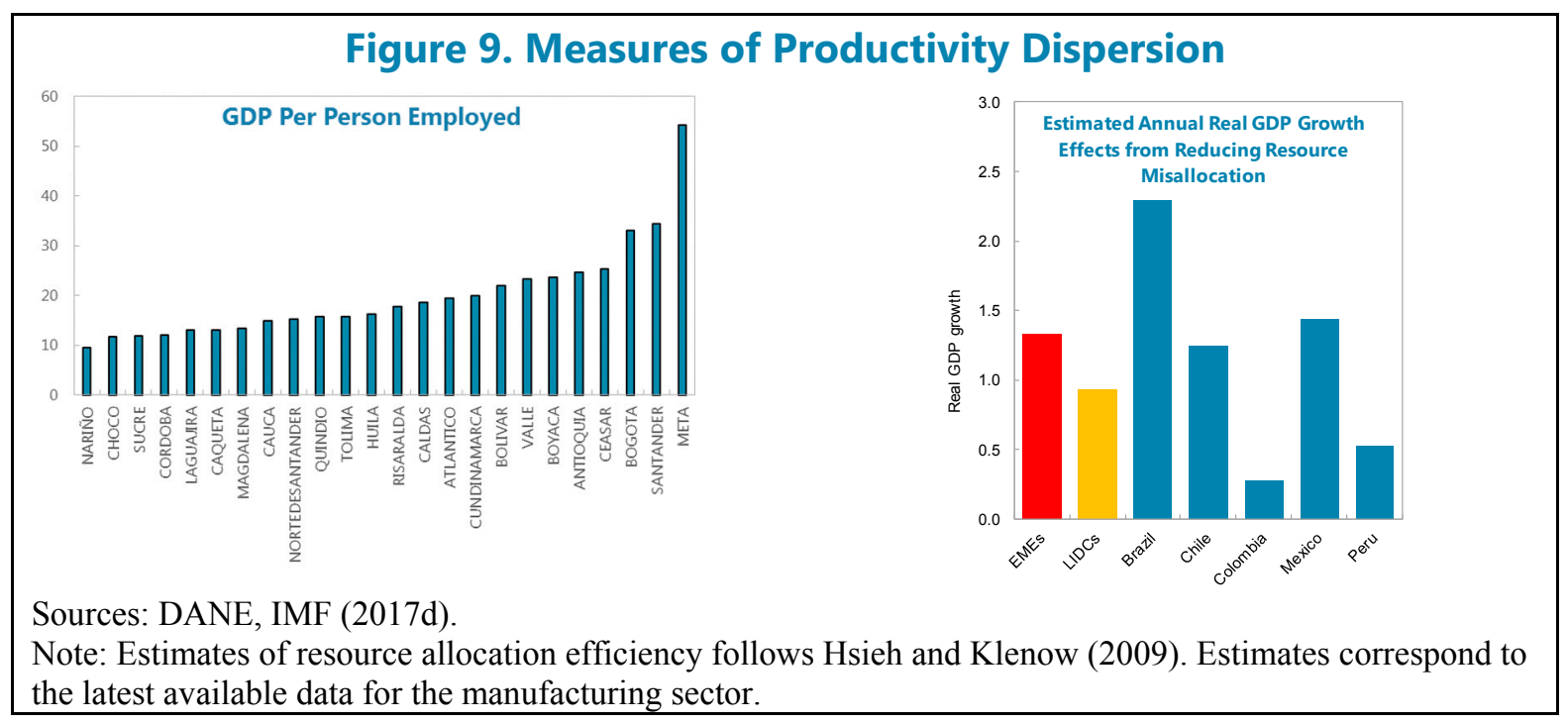

Another factor that may be hindering productivity growth is related to Colombia's relatively low spending in R\&D. DNP (2016) notes this issue, as well as the little coordination between centers producing knowledge and the private sector, and points out a number of policy measures to address it.

Going forward, policy initiatives such as the $\mathbf{4 G}$ investment program and developments such as the peace agreement with the FARC bode well for productivity growth. The next subsection examines possible productivity paths for the next five years and discusses their implications for potential growth.

Productivity growth could reach above one percent in a scenario with very strong reform implementation but could be much weaker in the absence of reforms. TFP growth would gradually increase to 1.1 percent by 2022 if the positive effects of the following factors materialize in full:

- Productivity gains from better infrastructure ( 0.25 percentage points). Improvements in infrastructure as a result of the $4 \mathrm{G}$ projects will make the existing stock of capital and labor more productive, especially in rural areas where the infrastructure gap is the largest. 
- The peace dividend ( 0.5 percentage points). Further improvements in security as a result of the peace agreement with the FARC will improve business confidence and productivity in the areas most affected by the conflict. Together with peace-related public spending, this will help close the large productivity gaps across firms and regions. In the long-run, the peace dividend could grow further, reaching up to 0.7 percentage points in terms of productivity growth.

- Tax reform (0.1 percentage points). The structural tax reform simplifies the tax code and reduces distortions, potentially increasing firm productivity.

- Ongoing efforts to improve the business environment and reduce barriers to trade (0.2 percentage points). Recent progress at the planning department (DNP) to streamline regulations and reduce subsidies in line with best OECD practices has the potential to improve productivity. The recently approved customs code and a planned simplification of import tariffs should make firms, especially exporters, more productive

\section{A. Potential Growth Projections}

Factor accumulation, including investment in machinery and equipment as well as labor, drove potential growth up to an average of 4 percent in the last 15 years. As discussed in the previous section, high population growth, a large drop in the unemployment rate, and improving schooling rates increased effective labor inputs significantly. Together with increasing capital accumulation and TFP gains since 2004, these developments lifted potential growth to above 4 percent on the eve of the global financial crisis.

Colombia's growth path was similar to other Latin American countries but remained below that of emerging Asia, mostly on account of lower TFP growth, as documented by Sosa and others 2013 (Figure 10). Others such as Loayza and others (2005) have also found that factor accumulation, rather than TFP, accounted for most of the growth observed in Colombia and the region.

Figure 10. Contributions to Real GDP Growth-Cross-Country Comparison

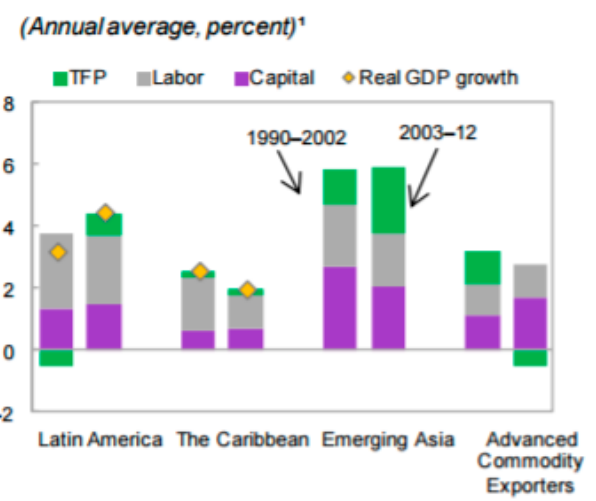

Source: Sosa and others (2013). 
- Putting all factors together, medium term potential growth would be in the 2.8 to 4.1 percent range depending on the strength of policies. The lower bound represents an unlikely scenario where incomplete reform implementation results in no TFP growth, and the effects of $4 \mathrm{G}$ infrastructure projects and the tax reform on investment do not materialize. The upper bound corresponds to one where TFP growth reaches a stable rate of around 1 percent by 2022, due to very strong structural reforms and full impact of policies on capital accumulation. A central scenario with medium term potential growth of 3.5 percent is shown in Figure 11. While less optimistic than the upper bound, the central scenario still involves a significant turnaround in productivity that requires strong reform implementation.

- Declining potential growth is a common theme among commodity exporters and highlights the importance of structural reforms to grow in a world of low oil prices. As Figure 12 shows, potential growth is expected to soften in most commodity exporters. In many cases, the decline is projected to be significantly larger than Colombia's.

\section{CONClusion}

Potential growth is likely to moderate to a range of 2.8 to 4.1 percent in a world of lower oil prices. The results from a production function and a MVF including oil prices indicate that potential growth rose to 4.5 percent in the era of high oil prices. Potential growth estimates fell considerably with the sharp drop in oil prices but the outlook is positive under successful implementation of the peace agreement and structural reforms:

- The $4 \mathrm{G}$ infrastructure projects and the tax reform will increase investment, offsetting the sharp decline in capital accumulation in the oil sector. Capital accumulation is projected to contribute 1.4 to 1.6 percentage points to average annual potential growth in 2017-22, highlighting the importance of executing $4 \mathrm{G}$ projects without delays. 


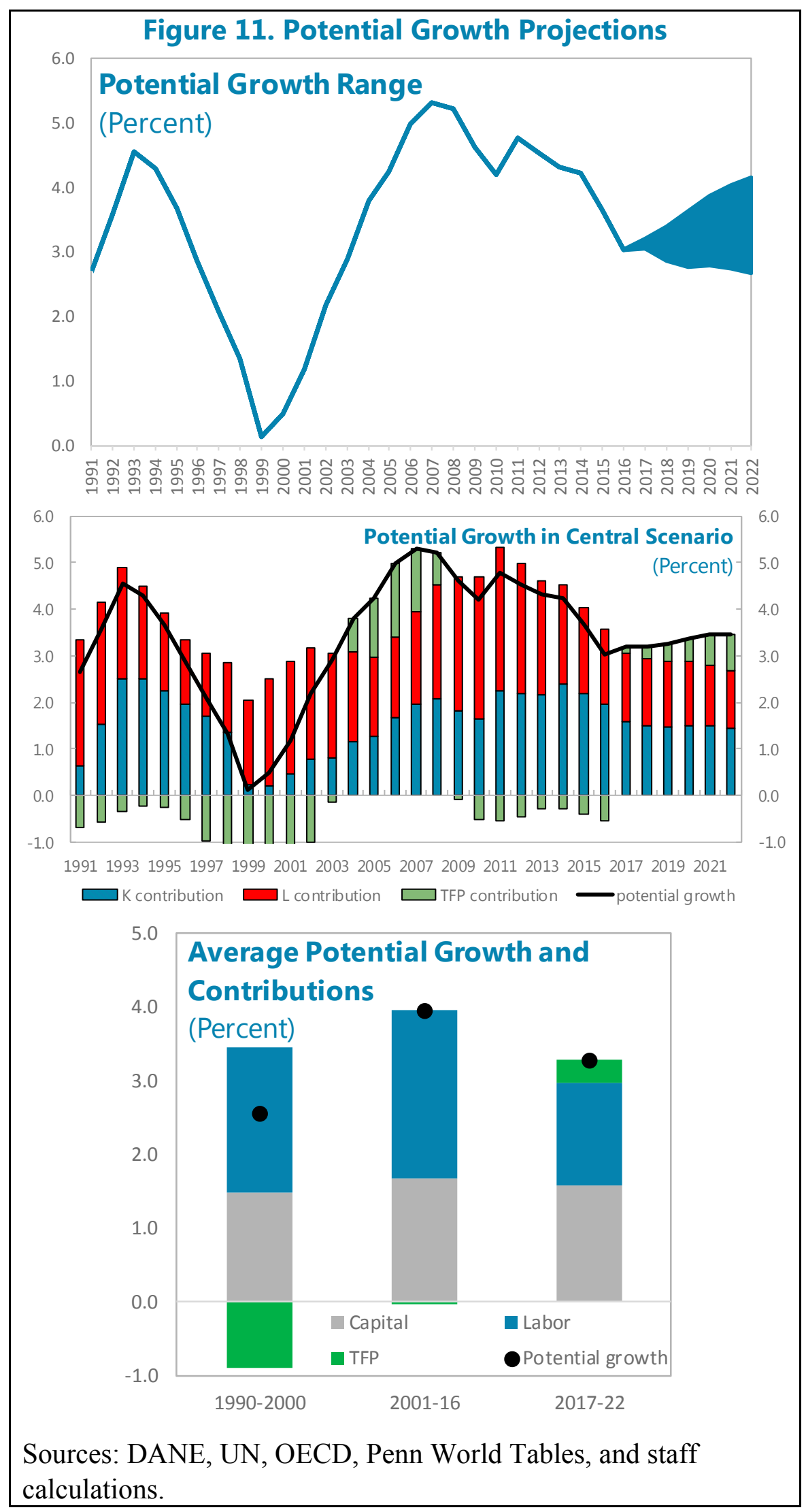


Figure 12. Potential Growth in Emerging Markets

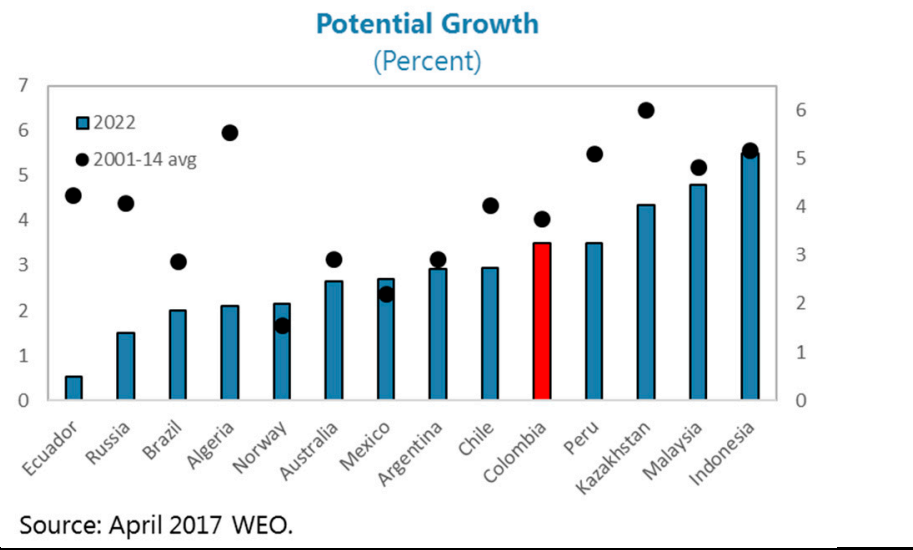

- Improvements in productivity are essential to lift potential growth. The large increases in the labor force observed in the last 15 years are unlikely to continue, making productivity-enhancing reforms central for growth. Better infrastructure, the peace agreement with the FARC, and ongoing efforts to improve the business environment and reduce trade barriers are welcome steps to boost productivity and growth.

- Oil prices stabilization should ameliorate further drag from oil-sector. A return to the oilrelated investment levels since in previous years is unlikely yet, the stabilization of oil prices (at around US $\$ 50$ dollars) could help prevent much further reduction in investment over the medium-term as suggested by regression analysis.

- The implementation of the peace agreement could contribute to potential GDP through different channels and is likely to also make it more inclusive. As noted in Box 3, the acceleration of potential GDP growth in the last decade was also accompanied with growing regional disparities. The peace agreement will contribute to narrow such disparities while increasing potential GDP. Private investment might respond to improved confidence and agro-industrial potential of the conflict area, while the comprehensive rural reform included in the peace agreement could buttress human capital and productivity. 


\section{Box 1. Structural Tax Reform}

Recent studies have highlighted Colombia's tax system as complex, prone to evasion and with limited progressivity. The complexity stems in part from multiple taxes for personal and corporate income and together with limited resources at the tax authority has led to widespread tax evasion (OECD, 2015). Relatively ample deductions and exemptions in personal income tax (PIT) reduce the progressivity of the system and erodes tax revenue. Further, the corporate income tax (CIT) rate was scheduled to reach 43 percent by 2018 which is relatively high and hinders business competitiveness. Colombia's total tax revenue is similar to other regional peers (Chile and Mexico) but is low compared to the OECD average.

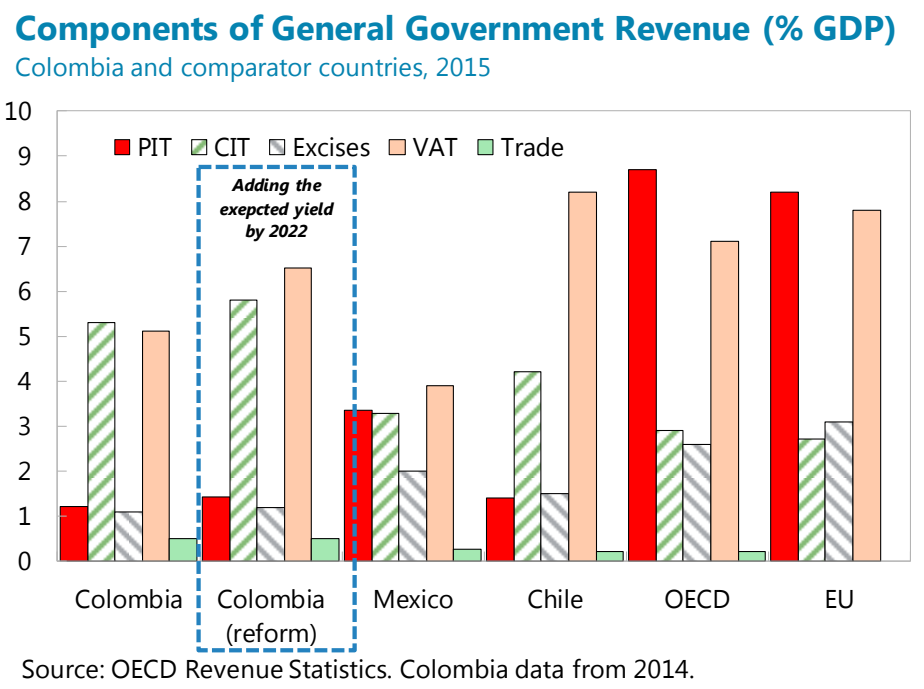

The 2016 structural tax reform aims to improve the efficiency and competitiveness of the tax system while increasing tax revenue. The reform replaces multiple overlapping taxes with a single tax for corporates and similarly establishes a single personal income tax with slightly reduced exemptions. The marginal CIT rate will be reduced gradually (to reach 33 percent in 2019) and VAT paid on capital goods will be credited against the CIT. Most of the reform's expected yield will come from an increase in the VAT rate and from gains in tax administration, formality and growth; while PIT revenue will increase only slightly.

Staff calibrated the FSGM model to simulate the growth impact of key measures of the reform. The model captures the fact that the reform will lead to higher public investment levels which would otherwise have been cut in order to meet the deficit targets included in the fiscal rule. Higher public capital would contribute to higher productivity (TFP). The combination of higher productivity and reduced corporate taxation will boost private investment and result in additional growth of about $0.3 \mathrm{pp}$. Staff also simulated the combined impact of the tax reform and the building phase of the 4G infrastructure agenda which would result in a combined growth boost of about $0.5 \mathrm{pp}$. (see SIP, Chapter 3 ). 
Box 2. The Impact of Infrastructure on Growth and Investment

Colombia and its regional peers score weakly in the quality of infrastructure dimension of the Global Competitiveness Report (GCR) by the World Economic Forum. The $4 \mathrm{G}$ projects are an opportunity to improve infrastructure and lift investment and potential growth.

Lanau (2017a) explores the impact of infrastructure improvements on growth and corporate investment in Colombia and Latin America exploiting the variation in the dependence of sectors in the economy on infrastructure and the variation in the quality of infrastructure across countries. The central assumption in the exercise is that sectors that depend relatively more on infrastructure to produce output will grow relatively faster when infrastructure improves.

The analysis is based on data on sectoral growth for 34 sectors in 61 countries for the period 1995-2011 come from the OECD input-output tables. Corporate investment data are from Orbis by Bureau van Dyjk. The measure of dependence on infrastructure at the sectoral level, constructed from the OECD input-output tables, is defined as the use of transportation inputs relative to output. Data on the quality of infrastructure come from the GCR by the World Economic Forum. The quantity of infrastructure is proxied by the kilometers of roads in a country.

Improving the quality and/or quantity of infrastructure increases growth in Colombia. More specifically, sectors that depend relatively more on infrastructure grow relatively faster when infrastructure improves. For example, if the quality of roads in Colombia according to the GCR improved to the sample median (the level in the Czech Republic), a sector with median dependence on

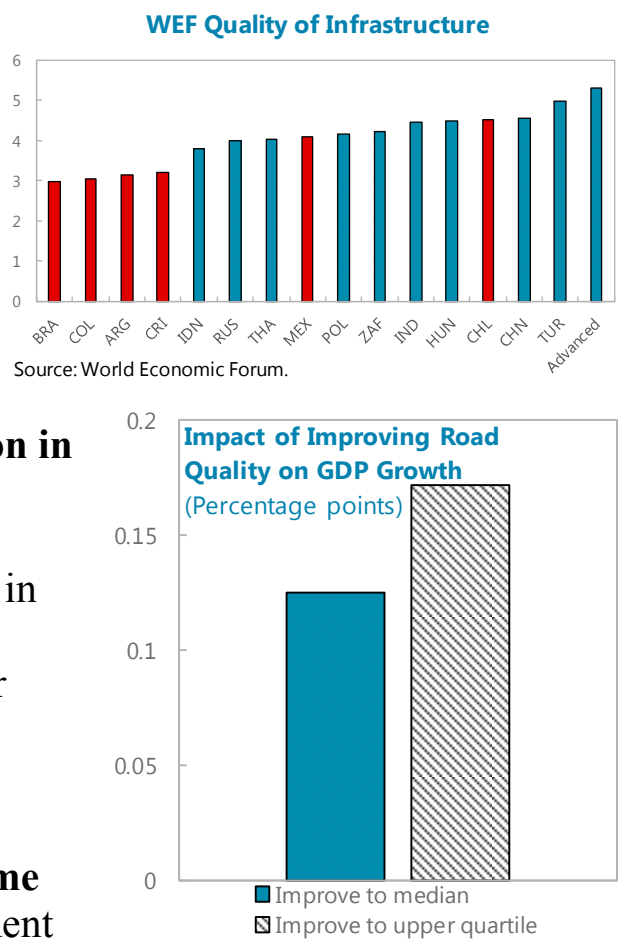

Source: Lanau (2017a)

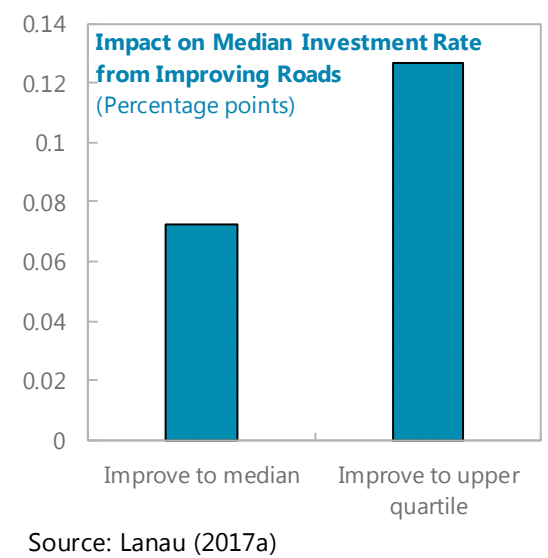

Source: Lanau (2017a) transportation (hotels and restaurants) would growth 0.15 percentage points faster. At the aggregate level, GDP growth would increase 0.12 percentage points. A 10 percent increase in the size of the road network would increase growth by 0.14 percentage points.

The corporate investment analysis is done at the firm level controlling for firm-specific determinants of investment such as leverage and cash flow. There is evidence that firms that depend relatively more on infrastructure increase investment when the quality of infrastructure improves. The investment rate of the median firm in Colombia would increase by about 0.1 percentage points if the quality of roads improved to the sample median. The largest estimated effects are in traditional sectors but given the subdued outlook for 
Box 2. The Impact of Infrastructure on Growth and Investment (Concluded) commodity prices, investment is unlikely to pick up substantially in the mining sector. The nontraditional sectors that stand to benefit the most from the depreciation in terms of investment are transport equipment, computers and electronics, and wholesale trade.

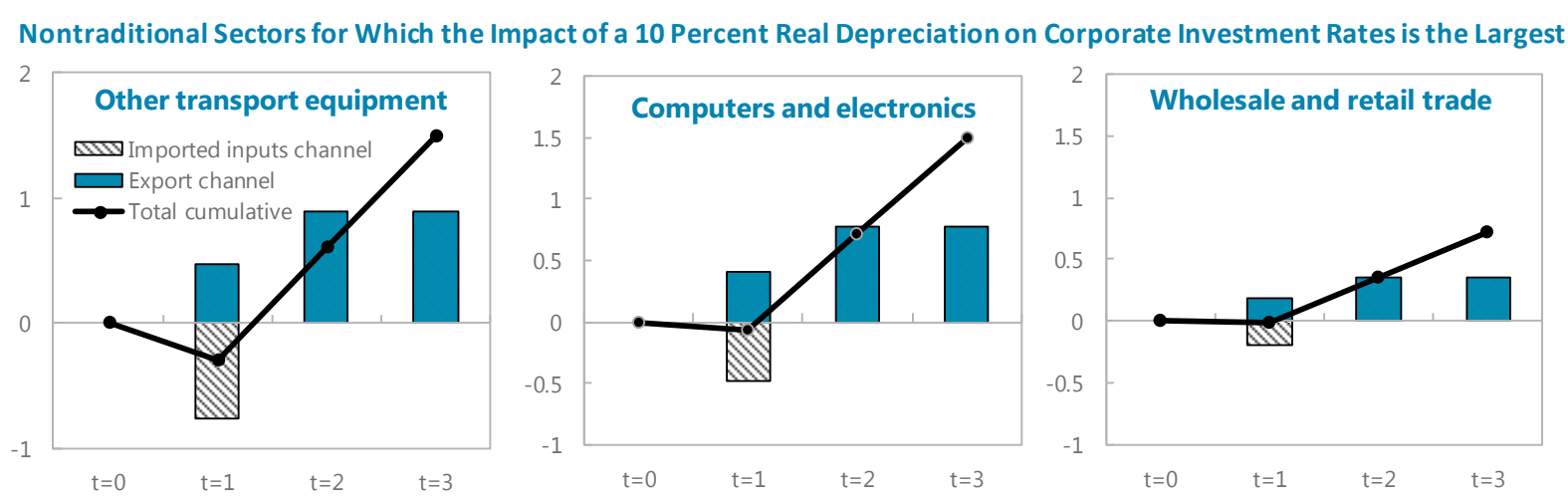

Cumulative Impact of 10 percent Depreciation

on Corporate Investment Rate

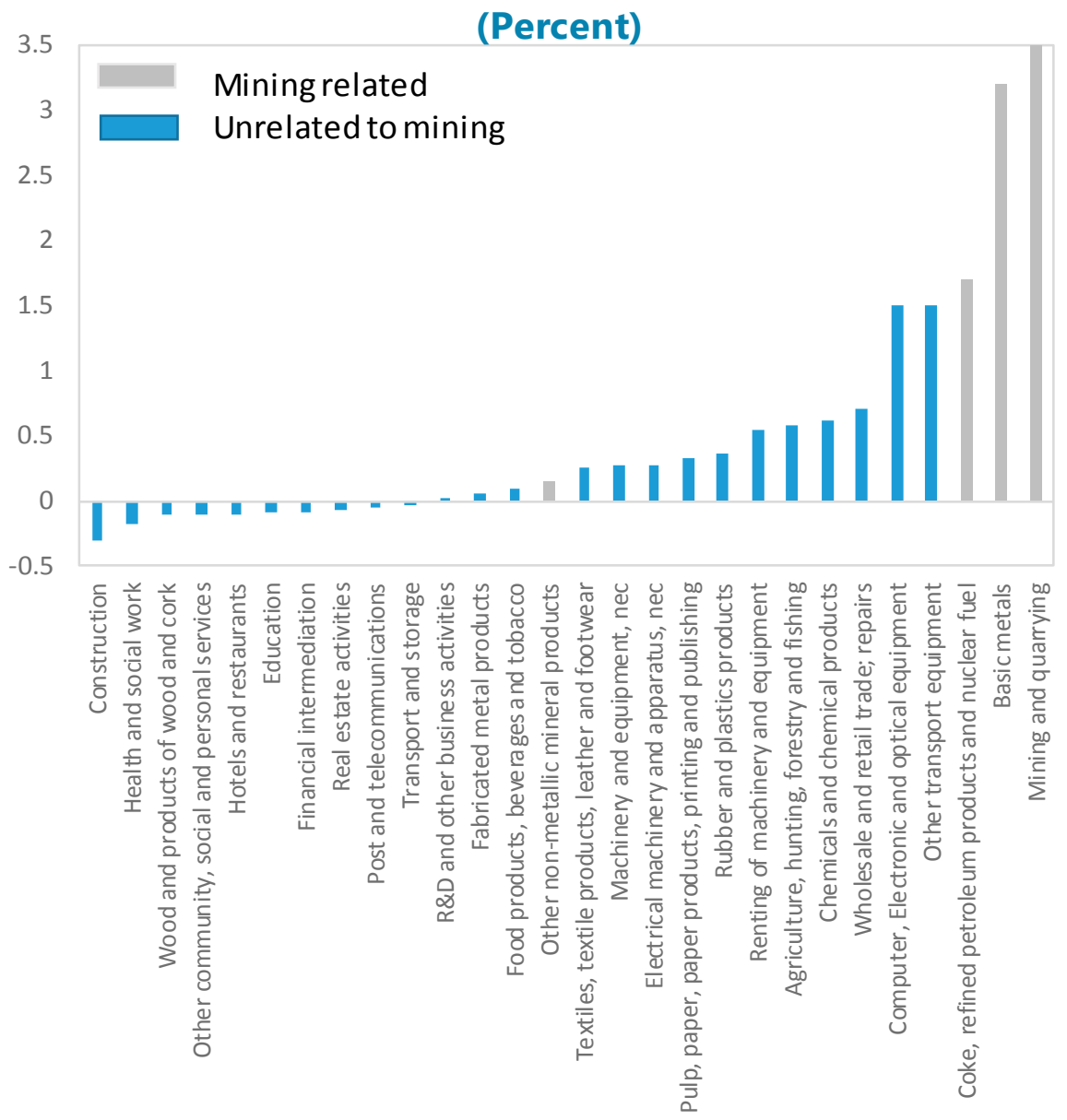

Source: Lanau (2017a). 
Box 3. Regional Convergence and Peace Agreement

Colombia's strong economic performance during the last decades masks important differences across regions. On average, GDP per capita expanded by 50 percent during 2000-15. However, while the top 5 regions (departmentos) doubled their GDP per capita during that time, in the bottom 5 regions GDP per capita actually declined by about 13 percent. Human capital differences are likely a contributing factor. While the national education attainment improved from 7 to 9 years (among 15 or older population), large difference remains with a 3-year gap between the top and bottom region (Bogota and Vichada, respectively).

The peace agreement has a strong focus on rural development and social inclusion. The agreement aims to reduce gaps in education, health, infrastructure and other public services among rural areas and help people displaced by the conflict back to agriculture activity including through land reform. The agreement also includes financial incentives to replace illicit drugs with alternative crops and measures to reincorporate guerrilla members into society. Tax incentives will be given to firms that invest/relocate to regions affected by the conflict. The agreement includes special courts to handle conflict-related crimes and allows guerrilla members to compete for political positions. The agreement also extends the victims' reparations program that started in 2011.

\section{The implementation of the} agreement will give priority to regions with the largest institutional and social gaps. The agreement will be implemented over 15 years. Short-term priorities include municipalities with significant coca production, FARC presence or lacking state presence. Other priority group includes municipalities affected by the conflict and with low income per capita, where private participation is expected to complement government programs as in the south and west part of the

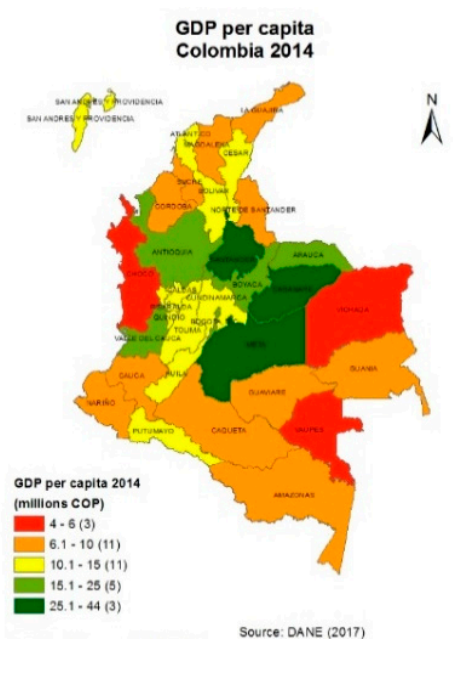
country (see maps). Incidence of Peace-Related Measures

(high intensity; low intensity)
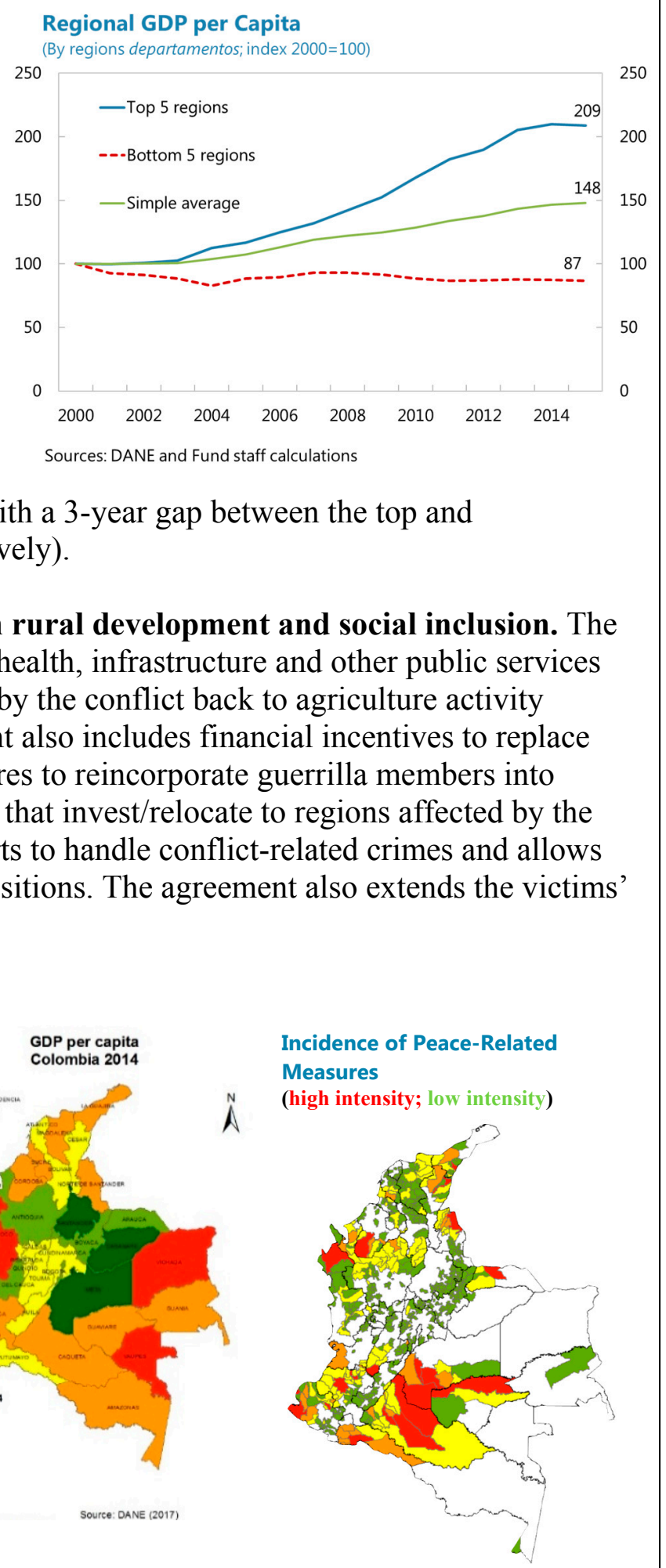
ANNEX

\section{A. Data Sources}

\begin{tabular}{|l|l|}
\hline Variable & Source \\
\hline GDP & DANE and staff projections \\
\hline Employment, unemployment, working age population & DANE \\
\hline Working age population projections & DANE and UN \\
\hline Human capital index & Penn World Tables \\
\hline Capital stock & DNP and Banrep \\
\hline Depreciation rate & Staff calculations \\
\hline Oil price & WEO \\
\hline
\end{tabular}

\section{Multivariate Filter-Technical Details}

The structure of the MVF in section C follows Blagrave and Santoro (2016) very closely. It contains two blocks of equations modeling the dynamics of GDP and oil prices. The first block is as follows

$$
\begin{gathered}
y_{t}=Y_{t}-\bar{Y}_{t} \\
\bar{Y}_{t}=\bar{Y}_{t-1}+G_{t}+\bar{\varepsilon}_{t}^{Y} \\
G_{t}=\theta G^{S S}+(1-\theta) G_{t-1}+\varepsilon_{t}^{G} \\
y_{t}=\varphi y_{t-1}+\varepsilon_{t}^{p}+\varepsilon_{t}^{y}
\end{gathered}
$$

Equation (1) states that the output gap $y_{t}$ is the log deviation of real GDP $\left(Y_{t}\right)$ from its potential level $\bar{Y}_{t}$. The stochastic process for output is described by equations (2)-(4). The level of potential output evolves according to potential growth $G_{t}$ and a level shock $\overline{\varepsilon_{t}^{Y}}$. Potential growth is also subject to shocks $\varepsilon_{t}^{G}$ that fade gradually according to the parameter $\theta$. The output gap is affected by demand shocks $\varepsilon_{t}^{y}$ and shocks to the price of oil $\varepsilon_{t}^{p}$. The block describing oil prices is as follows

$$
\begin{aligned}
& p_{t}=P_{t}-\bar{P}_{t} \\
& p_{t}=(1-\rho) p_{t-1}+\varepsilon_{t}^{p} \\
& \bar{P}_{t}=(1-\mu) \bar{P}_{t-1}+\bar{P}_{s s}+\varepsilon_{t}^{\bar{P}}
\end{aligned}
$$

Equations (5)-(7) break down oil prices into changes due to cyclical and trend shocks. The oil price gap $p_{t}$ is the deviation of the actual oil price $P_{t}$ from its trend or structural component $\bar{P}_{t}$. The price of oil is subject to temporary shocks $\varepsilon_{t}^{p}$, which will affect the output gap, and permanent shocks $\varepsilon_{t}^{\bar{P}}$, which affect potential output. The model is estimated using Bayesian methods. Priors are chosen following the guidance in Blagrave and Santoro (2016) and Blagrave and others (2015). Table 1 lists the priors and posterior estimates. ${ }^{1}$

\footnotetext{
${ }^{1}$ The steady state $\log$ oil price $P_{S S}$ is set to the sample average and G_ss to 3.70 .
} 


\begin{tabular}{|crrr|}
\hline \multicolumn{5}{c}{ Table 1. Priors and Posterior Estimates } & \\
\hline Parameter & Prior & Prior Standard Dev. & Posterior Estimate \\
\hline$\theta$ & 0.10 & 0.05 & 0.15 \\
$\varphi$ & 0.60 & 0.10 & \\
$\rho$ & 0.60 & 0.10 & 0.10 \\
$\mu$ & 0.60 & 0.10 & 0.10 \\
$G^{s S}$ & $\mathrm{~N} / \mathrm{A}$ & & 3.70 \\
$\overline{P_{S S}}$ & $\mathrm{~N} / \mathrm{A}$ & & 366.53 \\
$\bar{\varepsilon}_{t}^{Y}$ & 0.50 & 0.01 & 0.20 \\
$\varepsilon_{t}^{G}$ & 0.50 & 0.01 & 0.41 \\
$\varepsilon_{t}^{y}$ & 1.00 & 0.01 & 1.07 \\
$\varepsilon_{t}^{p}$ & 2.00 & 0.40 & 11.62 \\
$\varepsilon_{t}^{\bar{P}}$ & 1.00 & 0.40 & 5.09 \\
\hline
\end{tabular}




\section{REFERENCES}

Aslam, A., S. Beidas-Strom, R. Bems, O. Celasun, S. Kilic Celik, and Z. Koczan, 2016, "Trading on Their Terms? Commodity Exporters in the Aftermath of the Commodity Boom,” IMF Working Paper No. 16/27 (Washington: International Monetary Fund).

Blagrave, P. and M. Santoro, 2016, "Estimating Potential Output in Chile: A Multivariate Filter for Mining and Non-Mining Sectors," IMF Working Paper No. 16/201 (Washington: International Monetary Fund).

Cardenas, M., and S. Rozo, 2002, "Does Crime Lower Growth? Evidence from Colombia," Commission on Development and Growth, Working Paper No. 30.

DNP, 2016, "Política Nacional de Desarrollo Productivo," CONPES.

Feenstra, Robert C., Robert Inklaar and Marcel P. Timmer, 2015, "The Next Generation of the Penn World Table" American Economic Review, Vol. 105 (October), pp. 3150-82.

Gruss, B., 2014, “After the Boom-Commodity Prices and Economic Growth in Latin America and the Caribbean,” IMF Working Paper No. 14/154 (Washington: International Monetary Fund).

Hausman, R., L. Pritchett, and D. Rodrik, 2005, "Growth Accelerations," Journal of Economic Growth, Vol. 10, Issue 4.

Havik, K, K. Morrow, F. Orlandi, C. Planas, R. Raciborski, W. Roger, A. Rossi, A. ThumThysen, and V. Vandermeulen, 2014, "The Production Function Methodology for Calculating Potential Growth Rates and Output Gaps," European Commission Economic Papers No. 535.

International Monetary Fund, 2015, "World Economic Outlook: Uneven Growth: Short- and Long-Term Factors,” April (Washington).

International Monetary Fund, 2015, "Regional Economic Outlook: Western Hemisphere. Northern Spring, Southern Chills,” April (Washington).

International Monetary Fund, 2017a, “World Economic Outlook: Gaining Momentum?” Chapter 2, April (Washington).

International Monetary Fund, 2017b, Colombia: 2017 Article IV Consultation-Press Release; Staff Report; and Statement by the Executive Director for Colombia, IMF Country Report No. 17/138 (Washington). 
International Monetary Fund, 2017c, Colombia: Selected Issues, IMF Country Report No. 17/139 (Washington).

International Monetary Fund, 2017d, "Fiscal Monitor: Achieving More with Less," April (Washington).

Karpowicz, I., 2014, "Financial Inclusion, Growth and Inequality: A Model Application to Colombia (Washington: International Monetary Fund).

Loayza, N., P. Fajnzylber, and C. Calderón, 2005, "Economic Growth in Latin America and the Caribbean: Stylized Facts, Explanations, and Forecasts," (Washington: World Bank).

OECD, 2017, OECD Economic Surveys: Colombia 2017, OECD Publishing, Paris, http://dx.doi.org/10.1787/eco_surveys-col-2017-en.

Perry, G.E., W.F Maloney, O.S. Arias, R. Fajnzylber, A.D. Mason, and J. SaavedraChanduvi, 2007, "Informality: Exit and Exclusion," (Washington: World Bank).

Sosa, S., E. Tsounta, and H.S. Kim, 2014, "Is the Growth Momentum in Latin America Sustainable?” IMF Working Paper No. 13/109 (Washington: International Monetary Fund). 